Article

\title{
Flood Susceptibility Mapping through the GIS-AHP Technique Using the Cloud
}

\author{
Kishore Chandra Swain ${ }^{1, *}$, Chiranjit Singha ${ }^{1}$ (I) and Laxmikanta Nayak ${ }^{2}$ \\ 1 Department of Agricultural Engineering, Institute of Agriculture, Visva-Bharati, Sriniketan 731236, India; \\ singha.chiranjit@gmail.com \\ 2 ICAR-NINFET, 12 Regent Park, Kolkata 700040, India; laxmikanta8495@rediffmail.com \\ * Correspondence: kishore.swain@visva-bharati.ac.in
}

Received: 19 August 2020; Accepted: 23 November 2020; Published: 2 December 2020

\begin{abstract}
Flood susceptibility mapping is essential for characterizing flood risk zones and for planning mitigation approaches. Using a multi-criteria decision support system, this study investigated a flood susceptible region in Bihar, India. It used a combination of the analytical hierarchy process (AHP) and geographic information system (GIS)/remote sensing (RS) with a cloud computing API on the Google Earth Engine (GEE) platform. Five main flood-causing criteria were broadly selected, namely hydrologic, morphometric, permeability, land cover dynamics, and anthropogenic interference, which further had 21 sub-criteria. The relative importance of each criterion prioritized as per their contribution toward flood susceptibility and weightage was given by an AHP pair-wise comparison matrix (PCM). The most and least prominent flood-causing criteria were hydrologic (0.497) and anthropogenic interference (0.037), respectively. An area of $\sim 3000 \mathrm{sq} \mathrm{km} \mathrm{(40.36 \% )} \mathrm{was}$ concentrated in high to very high flood susceptibility zones that were in the vicinity of rivers, whereas an area of $\sim 1000 \mathrm{sq} \mathrm{km} \mathrm{(12 \% )} \mathrm{had} \mathrm{very} \mathrm{low} \mathrm{flood} \mathrm{susceptibility.} \mathrm{The} \mathrm{GIS-AHP} \mathrm{technique} \mathrm{provided}$ useful insights for flood zone mapping when a higher number of parameters were used in GEE. The majorities of detected flood susceptible areas were flooded during the 2019 floods and were mostly located within $500 \mathrm{~m}$ of the rivers' paths.
\end{abstract}

Keywords: flood susceptibility; geographic information system (GIS); analytical hierarchy process (AHP); Google Earth Engine (GEE); multi-criteria decision support system

\section{Introduction}

Flood is among the most severe natural disasters; it causes significant and irreversible damage to property and communication infrastructure, which leads to considerable loss of life, both human and livestock, along with loss of agricultural produce and farm lands. Some of the deadliest floods occurred in China (1935, 1931, 1887), Guatemala (1949), Bangladesh (1974), Venezuela (1999), Iran (1954), India (2013), Japan (1953), and Peru (1941), and many more, where loss of human life occurred in the range of several thousands. These natural disasters can be monitored properly using modern technology and information systems. There are some benefits associated with floods, such as transportation of fertile soil to farmlands and distribution of fishes to small water bodies; however, they have a devastating impact on the surrounding regions. Various diseases, such as cholera, typhoid fever, leptospirosis, hepatitis A, malaria, and dengue, spread because of the polluted water from these floods. Flood mapping can support in decision-making for such events by facilitating risk management, near real-time forecasting, and land use and land cover management (LU/LC). Floods are multi-dimensional dynamic phenomena; thus, geographic information system (GIS)/remote sensing (RS) data have been largely delineated to explore the extent of flooded areas. Near real-time flood monitoring is essential to mitigate floods and thus control their impact [1]. Sofia et al. [2] found that cumulative 
flood hazard delineation along with environmental degradation and climate change parameters associated with LU/LC changes can ensure better monitoring capability. The pixel-based flood analysis requires huge time and processing capabilities to achieve near real-time assessment. Flood vulnerability combines inundation extent with social data, which is used to determine flood-prone communities that have the greatest propensity for loss of property and life. Currently, flood exposure and vulnerability are mapped using hydrodynamic inundation models along with high-resolution population distribution data in developed countries with high population density [3]. Flood susceptibility mapping uses analysis techniques, such as multi-criteria decision analysis [4], logistic regression [5], frequency ratio approach [6], weight of evidences equations [7], k-nearest neighbor logic [8], analytic network process framework [9], Bayesian network fusion technique [10], and genetic algorithm-based rule-set production followed by the quick and unbiased efficient statistical tree (QUEST) technique for urban flood mapping in Oulu, Finland [11]. The adaptive neuro fuzzy interface system used for landslide susceptibility in Qazvin Province, Iran [12], hydraulic modeling used for estimating unsaturated soil hydraulic conductivity [13], and soil water assessment tool (SWAT) in the ArcGIS software environment [14] are some models utilized for flood susceptibility estimation. Deep learning methods, such as artificial neural networks (ANNs), fuzzy logic, support vector machines, random forest classification, regression trees (RTs), and classification and RT (CART) algorithms [15-17], have significant potential for effective flood mapping and monitoring. ANN has been extensively used for flood susceptibility mapping [18,19]; however, it has drawbacks, such as over-fitting and under-fitting, slow learning, the curse of dimensionality, and slow convergence to a local optimum; in addition, its performance for processing complex hydrological phenomena has been inadequate [20,21].

Tellman et al. [22] proposed a new approach for flood modeling by leveraging satellite images with a cloud computing-enabled Google Earth Engine (GEE) system to map flood hazards in real time in two ways: First, by generating a globally consistent flood inundation layer, and second, by dynamically modeling flood susceptible areas. A cloud computing GEE-based flood prevention and emergency response system (FPERS) has been successfully developed and implemented for three frontal applications of before, after, and during floods occurring during typhoons or torrential rain events in China from 2013 to 2016 [23].

The most preferred technique, the analytical hierarchy process (AHP), has been used to create a special decision-making framework for flood susceptibility mapping [24]. In AHP, various flood vulnerability parameters are ranked based on their impact using PCMs [25]. The selected methodological framework formulates the cumulative nature of each criterion, which is effective for generating flood data subject to the spatial scale, at local, regional, and national levels. With several rivers flowing through, Bihar is a flood-prone region; it constitutes $16.5 \%$ of the total flood area and is home to $22.1 \%$ of the flood-affected population of India [26].

\subsection{Flood Mapping Parameters}

Basic parameters, such as precipitation rate, river density, drainage network, soil erodibility, and rainfall erosivity, and topographical variations, such as elevation, slope, and ruggedness index, were measured and evaluated for identifying flood-causing factors at river banks [14,24].

A higher precipitation rate considerably increases the probability of floods in a flood-prone area, along with contribution from other parameters. High river network density in a region implies accelerated surface runoff and increases the possibility of flooding [27]. The drainage network density (in $\mathrm{km} / \mathrm{km}^{2}$ ) can be determined and mapped using the "line density" tool of the ArcGIS software. Flood intensity and frequency are very high around a drainage basin area [28], particularly closer to rivers. The ruggedness of terrain is associated with rugged, undulated, or heterogenous patterns of a terrain. A permeable formation favors rainwater absorption in ground, subsequently minimizing flood hazard. On the other hand, an impermeable formation, such as marly, clay, and gypsum, increase the runoff rate, amplifying flood risk in the region. Spatial distribution of topographic attributes that represent soil moisture, ground water depth, and soil wetness are described by the topographic 
wetness index (TWI). High values of TWI correspond to areas favoring water accumulation and high runoff. High TWI values signify low drainage, representing more saturated land, which may cause flash flooding [29]. LU/LC dynamics parameters affect hydrological processes components, such as infiltration, surface runoff, evaporation, and evapotranspiration [30]. In another study, LU/LC dynamics along with elevation and slope were considered factors that had the most significant effect on flooding in a region [31]. Forest and vegetation cover favors the infiltration rate and decreases the runoff depth, thus decreasing potential flood risks. However, barren land, rivers and river banks, impervious roads, and buildings lead to a higher runoff rate [32], as they are hard and impervious surfaces with minimal infiltration. Vegetation is a defensive factor against floods, as it cuts the runoff and acts as a barrier; it is generally estimated by the normalized differential vegetation index (NDVI) [33]. Urban centers are rapidly encroaching into agricultural areas and grass land that serve as natural retention zones for flood waters. This brings new challenges to manage flood water in urban areas [34]. According to Jebur et al. [35], the stream power index (SPI), a flood monitoring parameter, can be defined as the rate of discharge with the power of the erosion of the flowing water in a specific location, that is, SPI is the workflow of a river basin. SPI values are inversely related to the frequency of flood occurrence, that is, a low SPI value indicates more chances of flood inundation [32].

\subsection{Scope and Objectives}

Conventional flood mapping was carried out using few parameters because of slow image processing systems and complex ranking of susceptibility levels of the parameters. In some cases, flood susceptibility mapping parameters were limited to topographic parameters. With the availability of cloud platforms along with pair-wise comparison matrix (PCM)-based ranking of parameters in AHP, we attempted to incorporate several parameters for accurate prediction of flood susceptible zones in Bihar, which is one of the most flood-affected regions in India. Five major flood monitoring criteria were identified, namely hydrologic, morphometric, permeability, land cover dynamics, and anthropogenic interference criteria, which include 21 sub-criteria, for intelligent assessment and flood susceptibility mapping.

\section{Materials and Methods}

\subsection{Study Area}

In Bihar, $76 \%$ of the total population faces frequent flood threats that cause great devastation [36,37]. Bihar lies between $24^{\circ} 20^{\prime} 10^{\prime \prime}$ and $27^{\circ} 31^{\prime} 15^{\prime \prime} \mathrm{N}$ latitude and $83^{\circ} 19^{\prime} 50^{\prime \prime}$ and $88^{\circ} 17^{\prime} 40^{\prime \prime} \mathrm{E}$ longitude, with a study area of nearly $7388 \mathrm{sq} \mathrm{km}$. The average elevation is $53 \mathrm{~m}$ from mean sea level (Figure 1), with a very low slope of $0.006 \%$. The average temperature in the region is $25-35^{\circ} \mathrm{C}$ in summer (April-May), which goes down to $5{ }^{\circ} \mathrm{C}$ in winter (November-January). Bihar has a monsoon-type tropical climate with a mean annual rainfall of $1270 \mathrm{~mm}$, most of which(up to $85 \%$ ) is received in four months from mid-June to mid-October, mostly due to southwest monsoon. The study area has sandy alluvial soil that is rich in lime and often contains a high percentage of clay. The area comprises rich alluvial plains of the Indo-Gangetic basin, which is enriched by sedimentation from rivers, such as Burhi-Gandak, Gandak, Ghaghra, Kosi Mahananda, and Ganga, flowing through the middle of the state from west to east. These rivers have high potential to cause recurring floods in the study area.

Since 2015, there have been significant losses of human and animal life because of floods in Bihar (Table 1). In 2008 and 2019, 2500 and 1900 people died, respectively, along with considerable loss of domestic animals, crops, and property. The medium range flood that occurred in 2016 damaged nearly 76,000 houses and caused crop losses in 0.36 million ha of farmland [38]. 

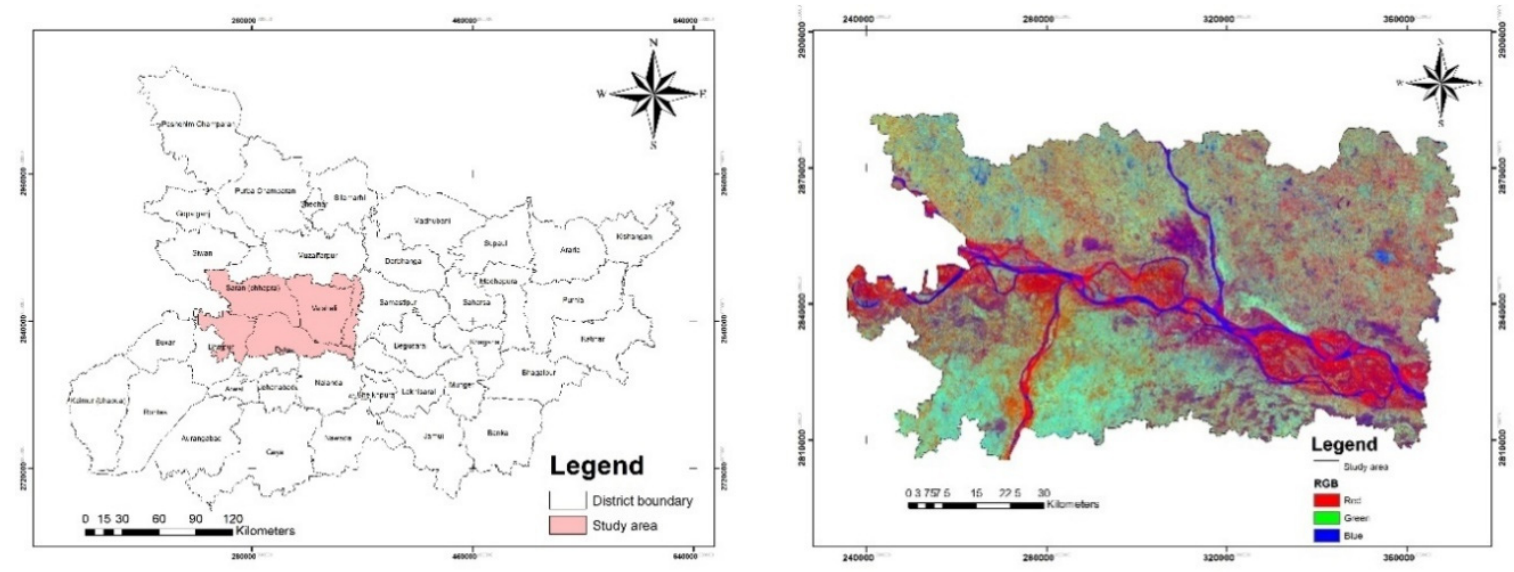

(a)
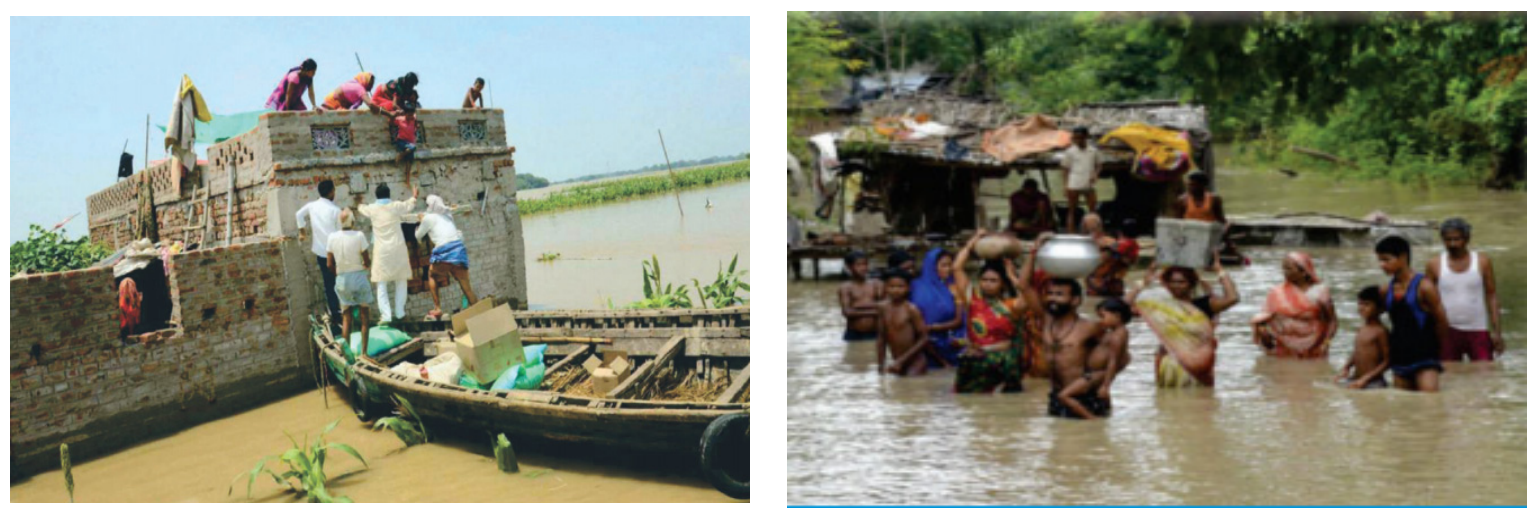

(b)

Figure 1. Study area identification, (a) location of the study area in Bihar, India, (b) flood situation [38].

Table 1. Statistics of loss of lives in floods of Bihar [37].

\begin{tabular}{cccccc}
\hline Year & Human & Animals & Year & Human & Animals \\
\hline 2019 & 1885 & 755 & 2005 & 58 & 4 \\
2018 & 1476 & 643 & 2004 & 885 & 3272 \\
2017 & 1521 & 792 & 2003 & 251 & 108 \\
2016 & 1254 & 5383 & 2002 & 489 & 1450 \\
2013 & 1201 & 140 & 2001 & 231 & 565 \\
2008 & 2534 & 845 & 2000 & 336 & 2568 \\
2007 & 1287 & 126 & 1999 & 243 & 136 \\
2006 & 36 & 31 & & & \\
\hline
\end{tabular}

\subsection{Source of Data}

Open-source spatial data for the study area and secondary information from several sources, such as local administration and land development and disaster management departments, were collected for flood susceptibility mapping (Table 2). Through an extensive literature review and expert opinions, five main criteria were selected and divided into 21 sub-criteria for flood susceptibility mapping. 
Table 2. Description of data sources used for processing flood conditioning criteria.

\begin{tabular}{|c|c|c|c|}
\hline SL No. & Data Type & Description & Source \\
\hline 1 & DEM & ASTER DEM (30 m) & usgs.gov.in \\
\hline 2 & Landforms & Global ALOS Landforms (30 m) & USGS/Google Earth Engine \\
\hline 3 & Precipitation (mm/day) & $\operatorname{TRMM}\left(0.25^{\circ}\right)$ & $\begin{array}{l}\text { https://giovanni.gsfc.nasa.gov/ } \\
\text { giovanni/ }\end{array}$ \\
\hline 4 & Soil data & $\begin{array}{l}\text { Soil Region and sub order } \\
\text { associations of India; RF 1:7,000,000 }\end{array}$ & NBSS and LUP, Nagpur \\
\hline \multirow[t]{2}{*}{5} & Soil moisture & $\begin{array}{l}\text { SMAP L-band radiometer data, } \\
\text { version } 1.0 \text { beta }(40 \mathrm{~km})\end{array}$ & https://www.mosdac.gov.in/ \\
\hline & $\begin{array}{l}\text { Soil erodibility }(\mathrm{K}) \text { and rainfall } \\
\text { erosivity }(\mathrm{R}) \text { factor }\end{array}$ & $\begin{array}{l}\text { RUSLE-based Global Soil Erosion } \\
\text { Modelling platform (GloSEM; } \\
\text { version 1.1), } 25 \mathrm{~km}\end{array}$ & $\begin{array}{l}\text { https://esdac.jrc.ec.europa.eu/ } \\
\text { content/globalsoilerosion }\end{array}$ \\
\hline 6 & Landsat 8 Images & $\begin{array}{c}\text { LANDSAT/LC08/C01/T1_TOA } \\
(30 \mathrm{~m})\end{array}$ & USGS/Google Earth Engine \\
\hline 7 & Land cover & $\begin{array}{l}\text { COPERNICUS/Landcover/100 } \\
\text { m/Proba-V/Global }\end{array}$ & $\begin{array}{l}\text { https://developers.google.com/ } \\
\text { earth-engine/datasets }\end{array}$ \\
\hline 8 & Population Density & $\begin{array}{l}\text { The Gridded Population of the } \\
\text { World, Version } 4 \text { (GPWv4) (30 arc s) }\end{array}$ & $\begin{array}{l}\text { https://sedac.ciesin.columbia.edu/ } \\
\text { data/collection/gpw-v4 }\end{array}$ \\
\hline 9 & GMIS & $\begin{array}{l}\text { Global Man-made Impervious } \\
\text { Surface (Landsat, v1) }\end{array}$ & $\begin{array}{l}\text { https://sedac.ciesin.columbia.edu/ } \\
\text { data/set/ulandsat-gmis-v1 }\end{array}$ \\
\hline 10 & HBASE & $\begin{array}{l}\text { Global Human Built-up and } \\
\text { Settlement Extent (Landsat, v1) }\end{array}$ & $\begin{array}{l}\text { https://sedac.ciesin.columbia.edu/ } \\
\text { data/set/ulandsat-hbase-v1 }\end{array}$ \\
\hline 11 & Road network & Road network in Bihar & $\begin{array}{l}\text { https://www.openstreetmap.org/ } \\
\text { export\#map=9/25.4172/85.1660 }\end{array}$ \\
\hline
\end{tabular}

\subsection{Flood Susceptibility Evaluation}

Various studies were referred for selecting the primary criteria for flood evaluation [10,27]. Twenty-one criteria were determined to be critical to causing floods and were thus focused on for predicting flood susceptible zones. These primary criteria were classified under five major groups based on similar properties and coherence, namely (I):hydrological criterion: precipitation, river network density, and SPI; (II): morphometric criterion: elevation, slope, profile curvature, landforms, ruggedness index, and distance from rivers; (III): permeability criterion: soil type, soil moisture, TWI, soil erodibility factor (K), and rainfall erosivity factor (R); (IV): LU/LC dynamics criterion: LU/LC, soil-adjusted vegetation index (SAVI), and NDVI; (V): anthropogenic interference: population density, global man-made impervious surface (GMIS), global human built-up and settlement extent (HBASE), and distance from roads.

All criteria were well-defined and preprocessed in the form of raster datasets. Their weights were estimated using AHP after ranking them based on the opinions of experts in the field of soil management, water resources, meteorology, disaster management, and local administration and professionals. A final flood susceptibility map was generated by the weightage linear combination method of AHP through multi-criteria analysis. A flow chart representing the procedure of the study is presented in Figure 2. All the main criteria and sub-criteria affecting floods in the study area were evaluated in the ArcGIS 10.5 software environment using the WGS84/UTM/Zone 45 North coordinate system. The ranges of an individual parameter, based on its likelihood toward the flooding zone, were classified into five susceptibility levels (5: very high, 4: high, 3: moderate, 2: low, and 1: very low) (Table 3). Susceptibility of individual criterion was evaluated and combined to estimate the susceptibility of a primary criterion (Figure 2). The selection and estimation of main and sub-criteria were carried out based on the following information. 


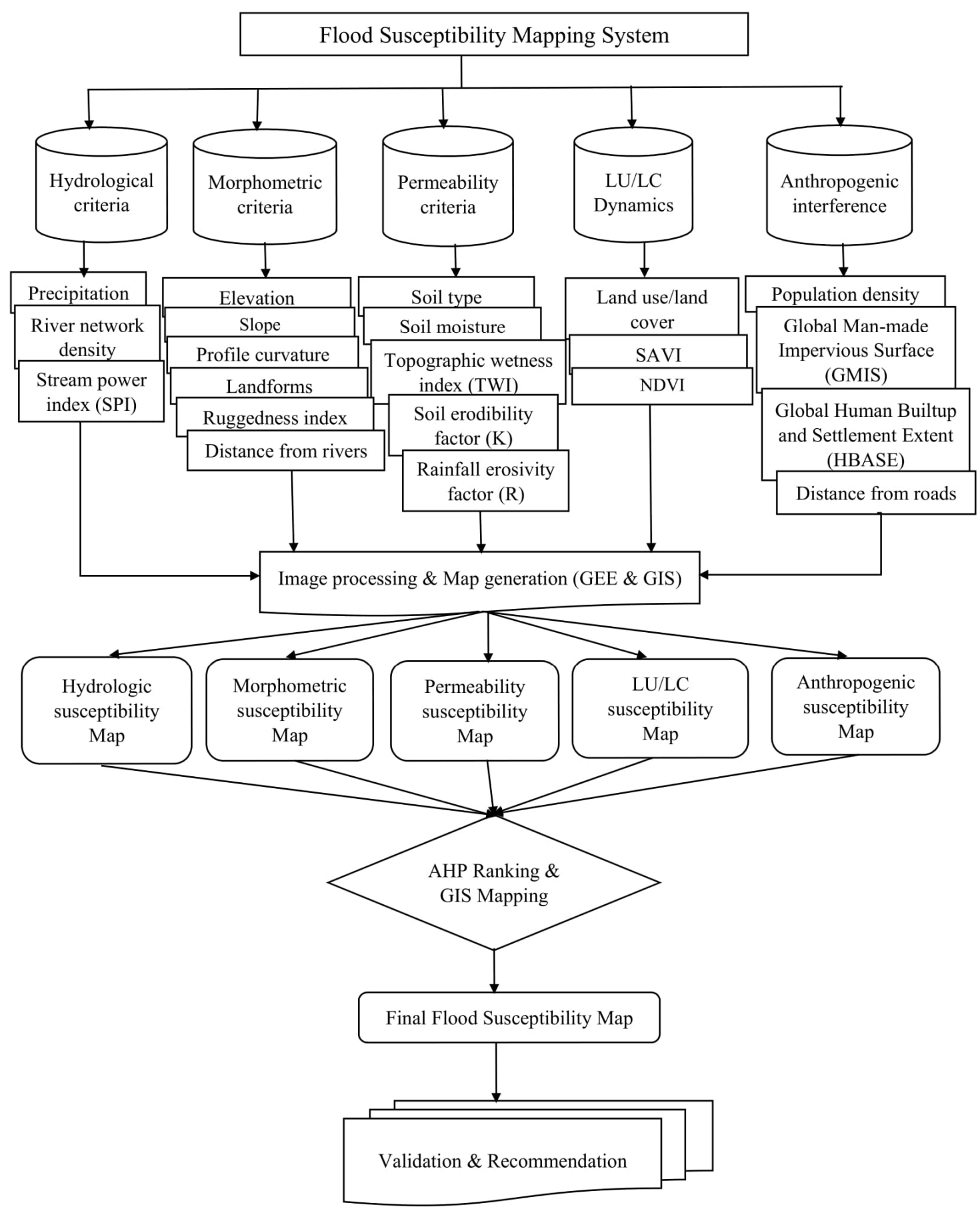

Figure 2. Schematic of the procedure used for flood susceptibility mapping in a region in Bihar, India. 
Table 3. Flood susceptibility criteria and sub-criteria ranges for flood susceptibility assessment.

\begin{tabular}{|c|c|c|c|c|c|c|}
\hline \multicolumn{2}{|c|}{ Flood Causative Criterion } & \multicolumn{5}{|c|}{ Susceptibility Class Ranges and Ratings } \\
\hline & Unit & Very High (5) & High (4) & Moderate (3) & Low (2) & Very Low (1) \\
\hline \multicolumn{7}{|l|}{ (A) Hydrologic criterion } \\
\hline Precipitation & $\mathrm{mm}$ & $>7.50$ & $7.0-7.50$ & $6.50-7.0$ & $6.0-6.50$ & $<6.0$ \\
\hline River network density & $\mathrm{km} / \mathrm{km}^{2}$ & $>1.53$ & $1.26-1.52$ & $1.00-1.25$ & $0.70-0.99$ & $0-0.69$ \\
\hline Stream power index (SPI) & level & $0-0.005$ & $0.006-0.642$ & $0.643-0.990$ & $0.990-1.500$ & $>1.500$ \\
\hline \multicolumn{7}{|l|}{ (B) Morphometric criterion } \\
\hline Elevation & $\mathrm{m}$ & $0-20$ & $20-50$ & $50-100$ & 100-150 & $>150$ \\
\hline Slope & $\left({ }^{\circ}\right)$ & $0.0-2$ & $2.1-5.0$ & $5.1-15.0$ & $15.1-35.0$ & $>35$ \\
\hline Profile curvature & radians/m & $0-0.25$ & $0.26-0.90$ & $0.91-2.5$ & $2.56-3.00$ & $3.00-3.50$ \\
\hline Landforms & level & $\begin{array}{l}\text { Valley, Valley } \\
\text { (narrow) }\end{array}$ & Lower slope (flat) & Upper slope (warm) & $\begin{array}{l}\text { Upper slope, Upper slope } \\
\text { (flat) }\end{array}$ & Peak/ridge (warm) \\
\hline Ruggedness index & level & $0.11-0.32$ & $0.33-0.42$ & $0.43-0.51$ & $0.52-0.60$ & $0.60-0.88$ \\
\hline Distance from rivers & $\mathrm{m}$ & $<200$ & $200-500$ & 501-1000 & 1001-1500 & $>2000$ \\
\hline \multicolumn{7}{|l|}{ (C) Permeability } \\
\hline Soil type & level & Silty clay & $\begin{array}{l}\text { Limestone and Marly, } \\
\text { Limestone and Dlomies, } \\
\text { Limestone Marly, and Gypsum }\end{array}$ & $\begin{array}{l}\text { Alluvium, Silty sediments } \\
\text { and Quaternary sediments }\end{array}$ & $\begin{array}{l}\text { Sandy clay sand and } \\
\text { conglomerate }\end{array}$ & Coarse sand \\
\hline Soil Moisture & Average \% & $30.01-35.0$ & $25.01-30.00$ & $20.01-25.00$ & $15.01-20.00$ & $0-15.00$ \\
\hline Topographic wetness index (TWI) & level & $>20.01$ & $15.01-20.00$ & $10.01-15.00$ & $0.001-10.00$ & $<0.001$ \\
\hline Soil erodibility factor $(\mathrm{K})$ & level & $>0.175$ & $0.170-0.175$ & $0.133-0.169$ & $0.107-0.132$ & $<0.106$ \\
\hline Rainfall erosivity factor (R) & level & $>5000$ & $4500-5000$ & $4200-4500$ & $4000-4200$ & $<4000$ \\
\hline \multicolumn{7}{|l|}{ (D) Landcover Dynamics } \\
\hline Landuse and landcover (LU/LC) & level & River, urban & Agriculture land & Wet land, shrubs, bare land & Low vegetation & Mixed forest \\
\hline SAVI & level & -0.50 to -0.30 & -0.29 to -0.22 & -0.22 to -0.13 & -0.12 to -0.02 & -0.02 to 0.14 \\
\hline NDVI & level & $>-0.02$ & -0.02 to 0.30 & $0.31-0.40$ & $0.41-0.50$ & $0.51-0.65$ \\
\hline \multicolumn{7}{|l|}{ (E) Anthropogenic interference } \\
\hline Population density & Person $/ \mathrm{km}^{2}$ & $>8000$ & $6001-8000$ & $4001-6000$ & $2001-4000$ & 2000 \\
\hline Human built-up extent & level & $>200$ & $151-200$ & $101-150$ & $51-100$ & $0-50$ \\
\hline Impervious area & $\%$ & $>150$ & $101-150$ & $51-100$ & $21-50$ & $0-20$ \\
\hline Distance to road network & $\mathrm{m}$ & $0-25$ & $26-50$ & $51-100$ & $101-150$ & $>150$ \\
\hline
\end{tabular}




\subsubsection{Hydrological Criterion}

Hydrological criterion comprised three parameters: precipitation, river network density, and SPI. Six weather stations distributed across Bihar were considered individual grids for precipitation mapping. The values of average precipitation for 2010-2019 were collected and distributed over the study area through geostatistical interpolation, which is called krigging. The drainage network density (in $\mathrm{km} / \mathrm{km}^{2}$ ) was determined and mapped using the "line density" tool of the ArcGIS software environment. It was estimated as the ratio between the total length of "river segments" to the total "drained area" or drainage basin [39]. According to Jebur et al. [35], SPI is defined as the rate of discharge, with power of erosion of the flowing water, within a specified location, i.e., it is the workflow in a river basin and can be given using Equation (1):

$$
\mathrm{SPI}=\left(\mathrm{A}_{\mathrm{s}} \tan \beta\right),
$$

where $A_{s}$ is the basin area $\left(\mathrm{m}^{2} \mathrm{~m}^{-3}\right)$, and $\beta$ is the radiant of slope (in degree).

\subsubsection{Morphometric Criterion}

The six relevant flood sub-criteria grouped under morphometric criterion are elevation, slope, profile curvature, landforms, ruggedness index, and distance from rivers. The elevation map of the study area was estimated from a digital elevation model (DEM) with a spatial resolution of $30 \times 30 \mathrm{~m}$ using Advanced Spaceborne Thermal Emission and Reflection Radiometer (ASTER) DEM in the GIS software environment. A slope map was also generated from the above DEM. The profile curvature was also estimated, which is defined as the difference between convex and concave surfaces. Landforms map was extracted from Global ALOS Landforms (with a 30-m resolution) and was processed by the GEE API code editor. Another important flood evaluation criterion is "distance from rivers", where abundant runoff causes frequent flooding. The classes for the raster of "distance from rivers" were estimated according to the natural break grading method using the "Euclidean distance" tool in the ArcGIS software environment using a map with a spatial resolution of 1:50,000. Because of the discrete character of a single maximum elevation, the ruggedness index is simply calculated using Equation (2), using the Melton ruggedness number for flow accumulation index [40]:

$$
\text { R.I. }=\left(Z_{\max }-Z_{\min }\right) / \sqrt{ } A \text {, }
$$

where R.I. is the ruggedness index; $Z_{\max }$ and $Z_{\min }$ are the maximum and minimum elevations, respectively; and $A$ is the total study area $\left(\mathrm{km}^{2}\right)$.

A low ruggedness value implies a gentle slope with less fragmentation or undulation of relief with a highly eroded surface [41].

\subsubsection{Permeability}

Permeability criterion were considered primary criterion for identifying flood susceptibility zones. Permeability influences the volume of peak flood wave and timing of occurrence and the groundwater flow from aquifers to support lower river flows [42]. Permeability includes five sub-criteria, namely soil type, soil moisture content, TWI, soil erodibility factor (K), and rainfall erosivity factor (R). Permeability significantly affects soil moisture, water infiltration, runoff, and inundation flooding frequency. The soil type map was collected in a vector format and converted to a raster format with spatial resolution of $20 \mathrm{~m}$. The maps were collected from the National Bureau of Soil Survey and Land Use Planning (NBSS\&LUP), Nagpur, India, with a spatial resolution scale of RF 1:7,000,000. Soil moisture active-passive (SMAP) in GeoTiff format in L-band radiometer was retrieved from www.mosdac.gov.in. The wetness index data was also estimated from the DEM. TWI was estimated as follows (Equation (3)):

$$
\mathrm{TWI}=\ln (\alpha / \tan \beta),
$$


where $\alpha$ is the cumulative upslope draining area per contour length (unity), and $\tan \beta$ is the slope angle at the point of contact.

Soil erosion is an environmental problem occurring in zones with less or no vegetation cover. It degrades land and hydrologic systems in watersheds and accelerates sediment accumulation, causing frequent floods [43]. In this study, the quantitative Revised Universal Soil Loss Equation (RUSLE)-based Global Soil Erosion Modelling platform (GloSEM 1.1) approach was used to estimate the soil erodibility $(\mathrm{K})$, intensity of soil erosion problem (factor measured in terms of $\mathrm{th} \mathrm{MJ}^{-1} \mathrm{~mm}^{-1}$ ), rainfall erosivity (R), and soil loss due to rainfall (measured in MJ mm ha ${ }^{-1} \mathrm{~h}^{-1}$ year ${ }^{-1}$ ) [44].

\subsubsection{LU/LC Dynamics}

The LU/LC map for the study region was extracted from quality indicator discrete dynamic land cover map (CGLS-LC100). Maps with a spatial resolution of $100 \mathrm{~m}$ were retrieved by GEE Data Cataloging. According to Goffi et al. [45], Outlook-Web-Access (OWA) segmented with SAVI that was based on variable cutoff values of spectral indices was used to produce digital maps of flooded areas distributed around the study area. In our study, the GEE platform utilized the resampling cubic convolution of Landsat 8 (Collection-1 Tier-1) calibrated reflectance values for Path: 141 and Row: 42 (covering the study area) images with supporting metadata between 20 August 2019 and 20 October 2019 with cloud-free images ( $<5 \%$ cloud cover) for SAVI and NDVI analyses ([46,47]; Equations (4) and (5)):

$$
\begin{gathered}
\mathrm{SAVI}=1.5(\mathrm{NIR}-\mathrm{RED}) /(\mathrm{NIR}+\mathrm{RED}+0.5), \\
\mathrm{NDVI}=(\mathrm{NIR}-\mathrm{RED}) /(\mathrm{NIR}+\mathrm{RED}),
\end{gathered}
$$

where NIR = near infrared red band reflectance (band 5) and RED = red band reflectance (band 4).

\subsubsection{Anthropogenic Interference}

Anthropogenic interference criterion includes population density, global human settlement (GHSL) extent, impervious layer, and distance to road network. Our study used gridded population density data sets at a resolution commensurate with the hazard model output. A wide range of such data sets are available, such as GHSL and gridded population of the world (GPW) [48,49]. Segmentation methods, with cut off values, can automatically extract urban land or impervious surface layers [10]. Similar to the effect of the distance to rivers, floods may also occur along roads and in sloppy areas surrounding the roads [50]. Road construction results in an increased percentage of impervious surfaces, causing reduced groundwater recharge and changes in topography that in turn affect flow accumulation and high runoff. Flood susceptibility classes for the raster of distance to roads were defined the same as those for "distance to rivers" following the grading technique using the "Euclidean" distance tool with a vector layer in the ArcGIS software environment.

\subsection{AHP Modeling Approaches}

AHP is a multi-perspective multi-objective decision-making model that enables users and planners to quantitatively derive a scale of preference drawn from a set of alternatives [51]. Saaty [52] introduced a PCM method to construct weighting factors for individual criterion by applying a ranking scale [53], which was estimated and assessed by a random consistency index [52]. The average RI varied as per number of factors or for different matrix orders. The consistency ratio (CR) was defined for validation (Equation (6)), which was defined as the ratio of the consistency index $(C I)$ and the RI (Equations (6) and (7) [54]). To validate the weightage, $C R$ value should be $<0.1$; otherwise, the weights of the comparison matrix must be recalculated. The researchers applied the approximation technique [55] for calculating the final weights and normalized the PCM. The acquired weights were used to design the flood susceptibility technique (Equation (8)). In this method, hydrologic criterion, morphometric 
criterion, permeability, and land cover dynamics had a significant impact on flood occurrence in the study area, whereas anthropogenic interference had a low impact:

$$
\begin{gathered}
C R=\frac{C I}{R I}, \\
C I=\frac{\left(\lambda_{\max -n}\right)}{n-1},
\end{gathered}
$$

where:

CR: Consistency ratio;

CI: Consistency index;

$\lambda$ : Average value of consistency vector;

$n$ : Number of criteria; and

RI: Random CI randomly generated PCM, which was accessed from the table of random inconsistency indices [56].

To validate the criteria weights, the final $C R$ value should be low $(<0.10)$. However, a high $C R$ $(>0.10)$ value indicates inconsistent judgments, requiring re-estimation of the weights:

$$
S=\sum_{i} W_{i} X_{i} \prod_{j} C_{j}
$$

where:

$S:$ Susceptibility composite score;

$W_{i}$ : Weight given to the factor $i$;

$X_{i}$ : estimated score of the factor $i$; and

$C_{j}$ : Constraint $j$ score (0 to1).

\subsection{Validation of the Susceptibility Map}

The flood susceptibility maps were validated with pre- and post-flooding images of Bihar during 20-30 August 2019 and 20-30 September 2019. The ascending SAR Ground Range collection images of Sentinel $1 \mathrm{C}$ band were used with a $5 \times 5 \mathrm{~m}$ resolution. A speckle filter was applied followed by mosaicking of the raster image cells. A supervised classification technique was used to collect training data for the classifier. The geometry tool in the GEE code editor was used to collect representative samples of backscatter for each sample classifier for flood inundated areas to VV and VH backscatter (dB) images for both pre- and post-flood instances through thresholding. Classified inundated layer backscatter values were extracted for the classification of the inundated layer. Thus, a flooding map for the study area was extracted. The "Map Query" tool in the Arc GIS software was used to validate the final susceptibility map against the flooded area map for September 2019.

The final flood susceptibility map was also analyzed for flood distribution along the length of the river in the region. A 500-m "distance from the river" query was carried out on flood susceptible maps in the ArcGIS software environment. The distance of $500 \mathrm{~m}$ from river was selected based on the range of susceptibility (Table 2) for "distance from river" criterion under very high and high susceptibility classes.

\section{Results and Discussion}

\subsection{Flood Susceptibility Mapping}

The flood susceptibility map was created using the range of values for individual criterion in five classes. The combined flood susceptibility map for the five criteria was developed using the sub-criteria classified under each criterion. The primary criteria-based flood susceptibility maps were further used for developing the final flood zoning map. By applying the AHP, the relative importance 
of each criterion was estimated after constructing PCMs. The values of each row are compared with values of each column to determine the relative significance and to obtain a rating score. After applying the weighting sum of all causative criteria, the final flood susceptibility map was generated with a sigma max value of 5.32 and $C R$ value of $0.09(<0.1$, validated). The degree of influence of the hydrologic criterion in identifying flood susceptibility zones was highest, as evidenced by the weight of 0.497 , assigned by the MCA technique in AHP; the morphometric criterion weight was second highest at 0.259 . Land cover dynamics, permeability, and anthropogenic interference were considered least important with weights of $0.128,0.079$, and 0.037 , respectively (Table 4 ). However, each primary criterion can enhance flood susceptibility by itself at a given time.

Table 4. Pair-wise comparison matrix, and final weights $\left(w_{i}\right)$ for flood susceptibility criteria.

\begin{tabular}{lcccccc}
\hline & $\begin{array}{c}\text { Hydrological } \\
\text { Criterion }\end{array}$ & $\begin{array}{c}\text { Morphometric } \\
\text { Criterion }\end{array}$ & $\begin{array}{c}\text { Land Cover } \\
\text { Dynamics }\end{array}$ & Permeability & $\begin{array}{c}\text { Anthropogenic } \\
\text { Interference }\end{array}$ & Weightage \\
\hline $\begin{array}{c}\text { Hydrological } \\
\text { criterion }\end{array}$ & 1 & 3 & 5 & 6 & 8 & 0.497 \\
\hline $\begin{array}{c}\text { Morphometric } \\
\text { criterion }\end{array}$ & 0.33 & 1 & 3 & 4 & 7 & 0.259 \\
\hline $\begin{array}{c}\text { Land cover } \\
\text { dynamics }\end{array}$ & 0.2 & 0.33 & 1 & 2 & 5 & 0.128 \\
\hline Permeability & 0.167 & 0.25 & 0.5 & 1 & 3 & 0.079 \\
\hline $\begin{array}{c}\text { Anthropogenic } \\
\text { interference }\end{array}$ & 0.125 & 0.143 & 0.2 & 0.333 & 1 & 0.037 \\
\hline
\end{tabular}

Note: Sigma $\max =5.32, C R=0.09(<0.1$, valid $)$.

The flood susceptibility maps were produced by the AHP reclassification technique for21 sub criteria using data from recent flood events (Figure 3) and secondary topographic information. Susceptibility maps based on primary criteria were also evaluated (Figure 4). Based on hydrologic criterion susceptibility, very high and high susceptibility classes cover $34.26 \%$ and $27.85 \%$ of the total area, respectively. As per the morphometric criterion, the share of the moderately susceptible class was $26.60 \%$, while the low susceptibility class had a coverage area of $28.68 \%$. Low susceptible criteria, such as permeability and land cover dynamics, had shares of $12.36 \%$ and $0.01 \%$, respectively, in the very low susceptibility class. The anthropogenic criterion was the most susceptible to floods with very low susceptibility in $49.83 \%$ of the area, while $12.27 \%$ of the area was under moderate susceptibility (Table 5). The final flood susceptibility map estimated through the AHP-GIS technique had $13.57 \%$ and $12.36 \%$ areas under very high and very low flood susceptibility classes, respectively (Figure 5). The high flood susceptibility class covered an area of $26.79 \%$ (Table 5), showing the majority of the study area as flood prone.

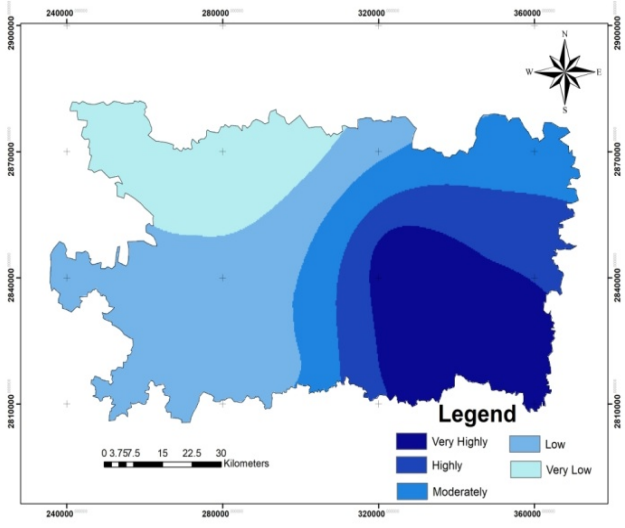

(a)

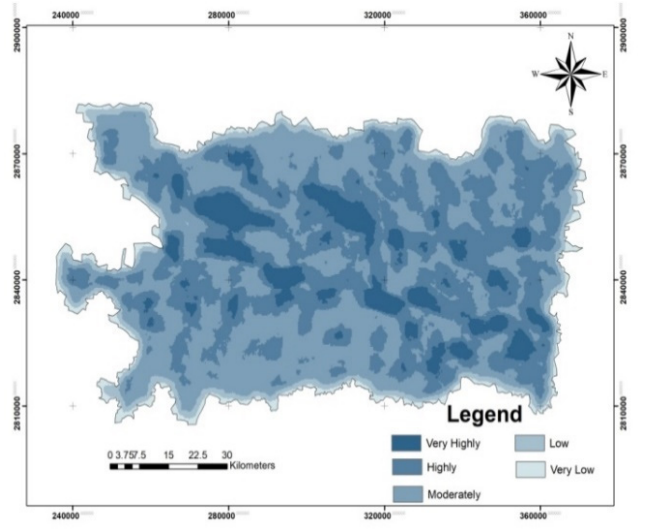

(b)

Figure 3. Cont. 


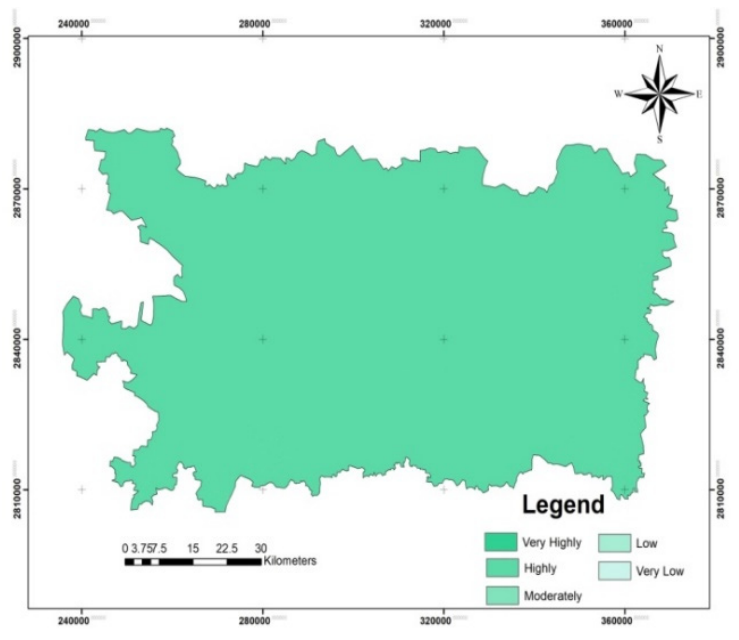

(c)

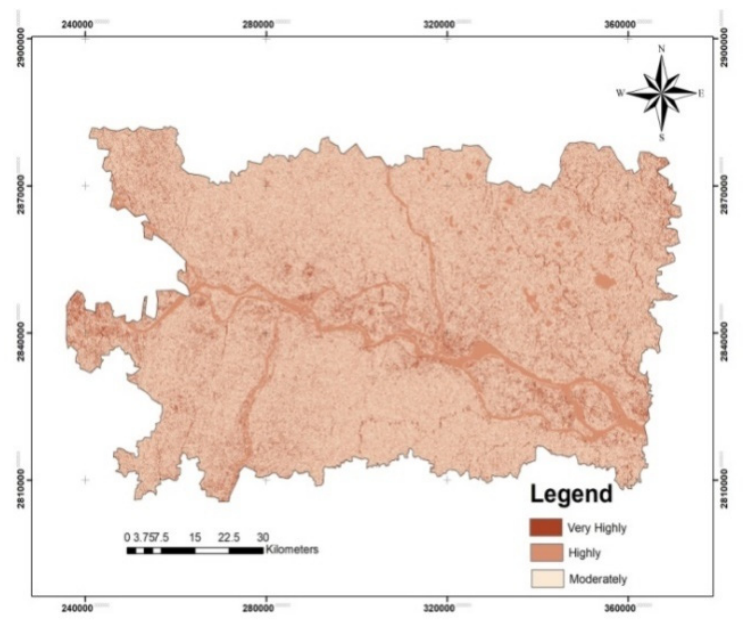

(e)

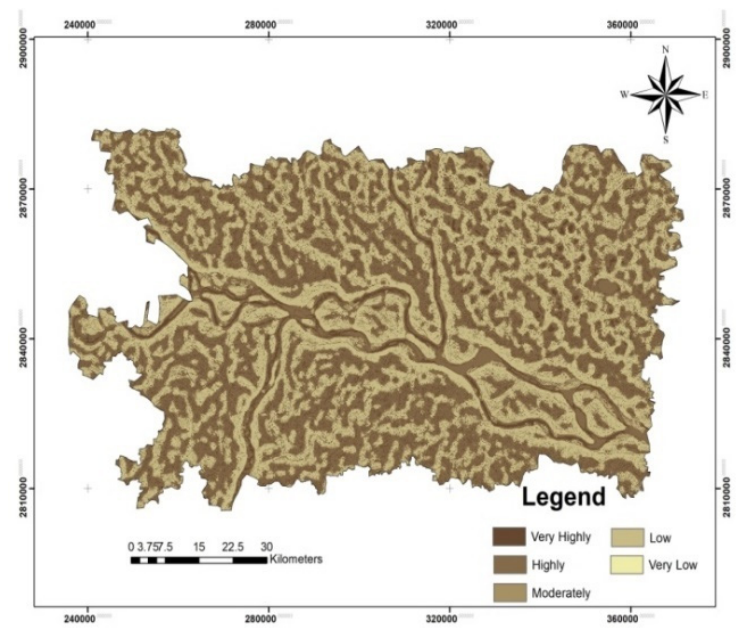

(g)



(d)



(f)

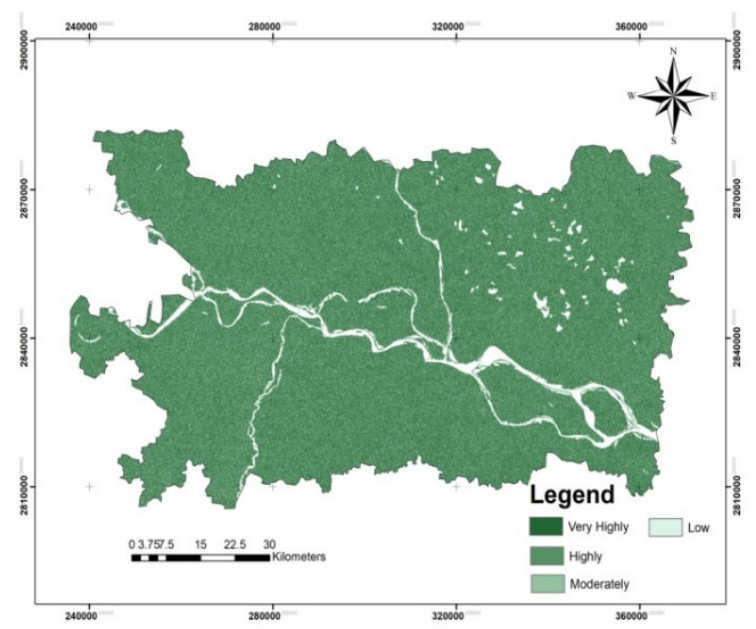

(h)

Figure 3. Cont. 


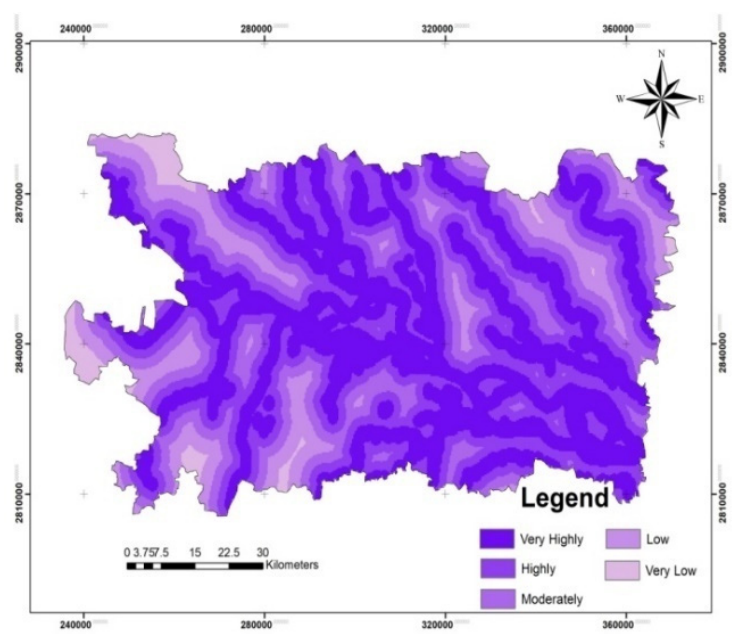

(i)

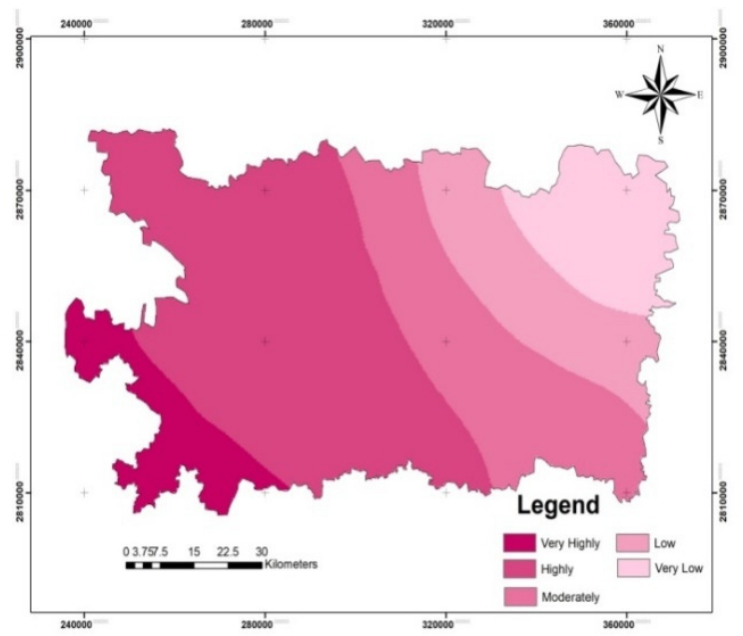

(k)

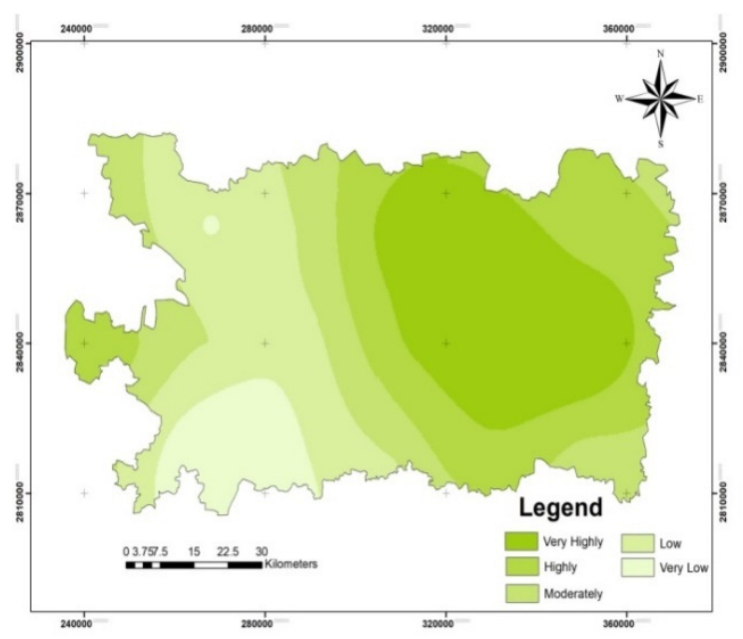

(m)

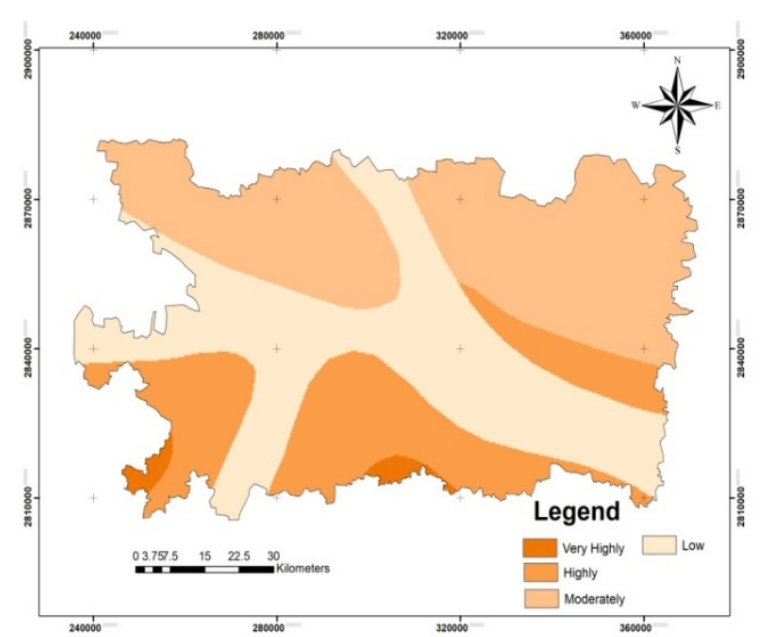

(j)

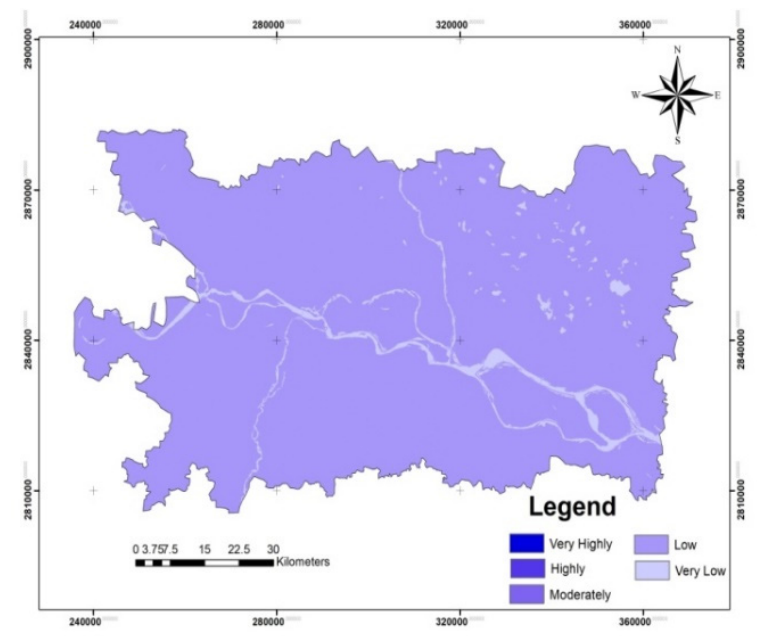

(l)

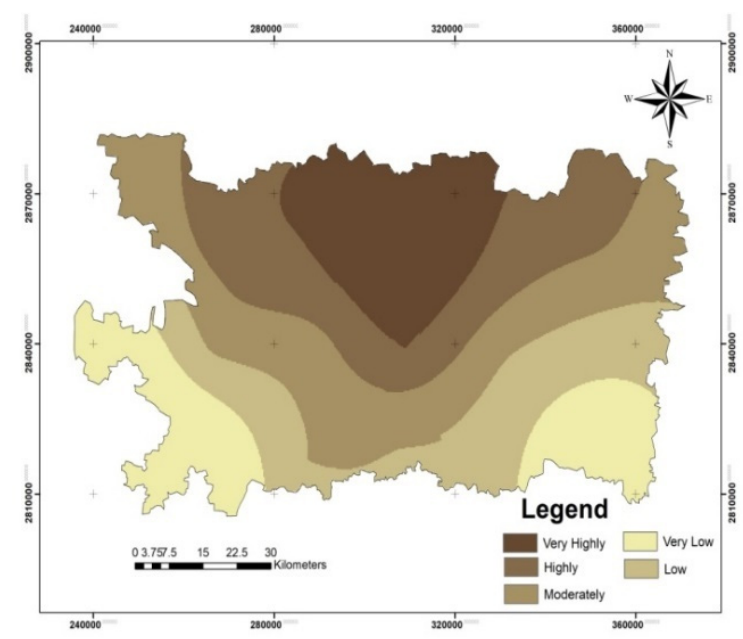

(n)

Figure 3. Cont. 


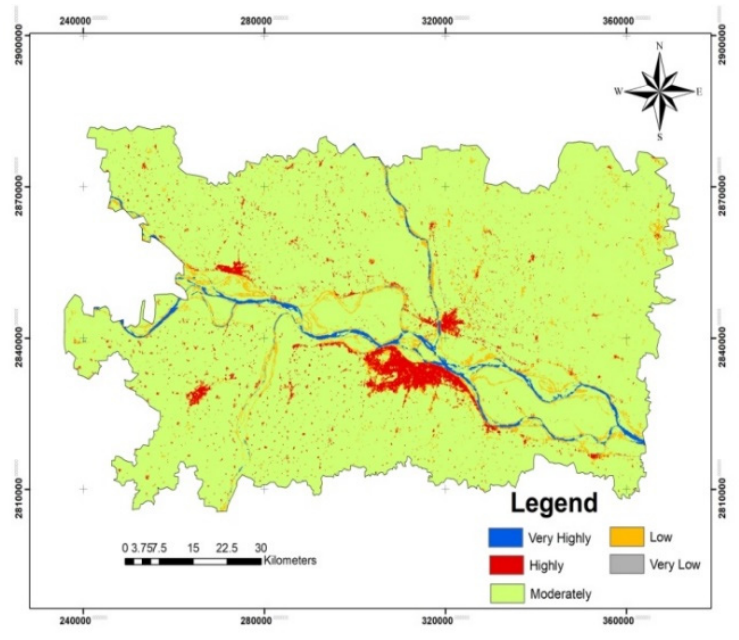

(o)



(q)

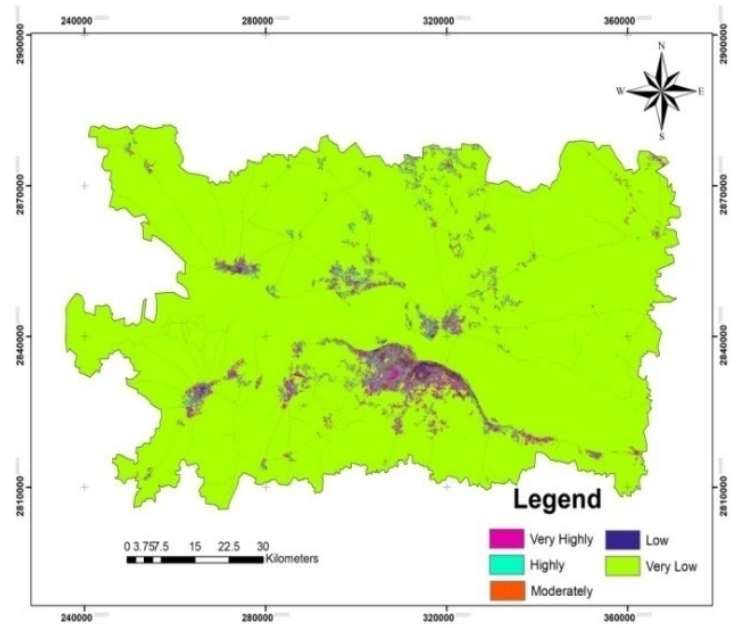

(s)

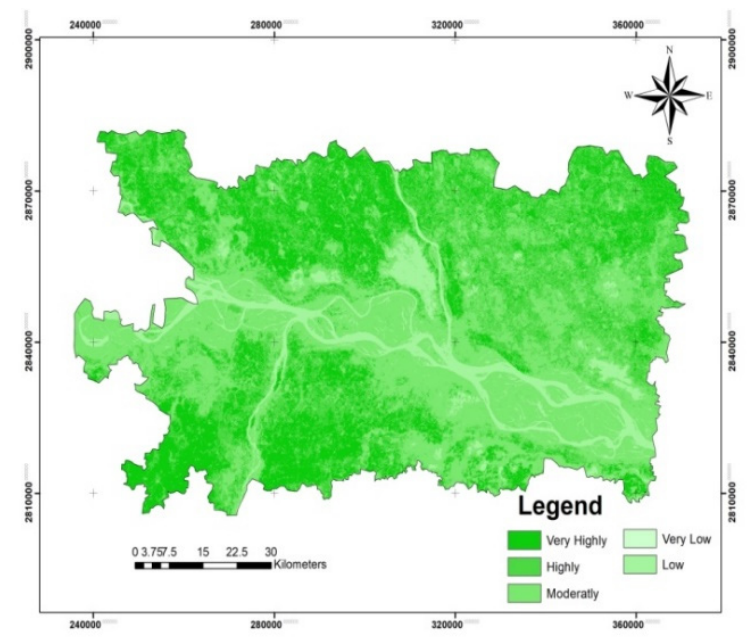

(p)

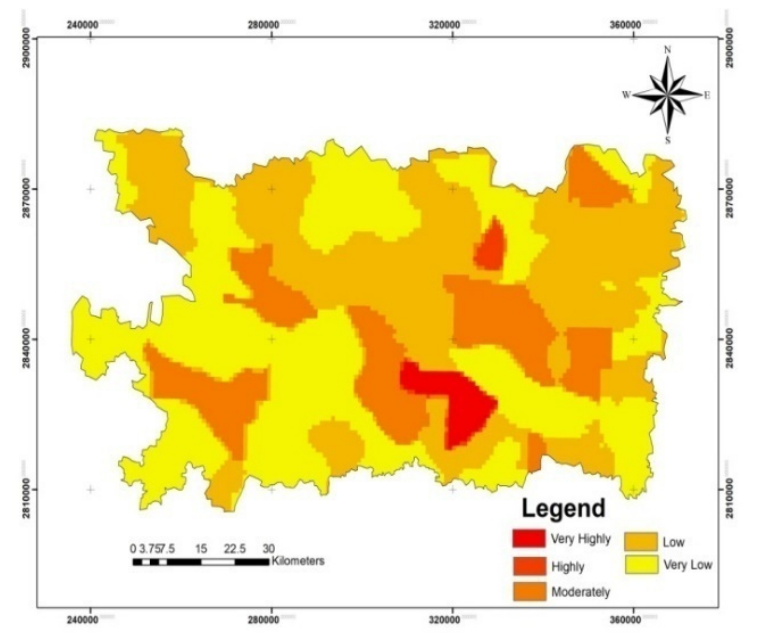

(r)

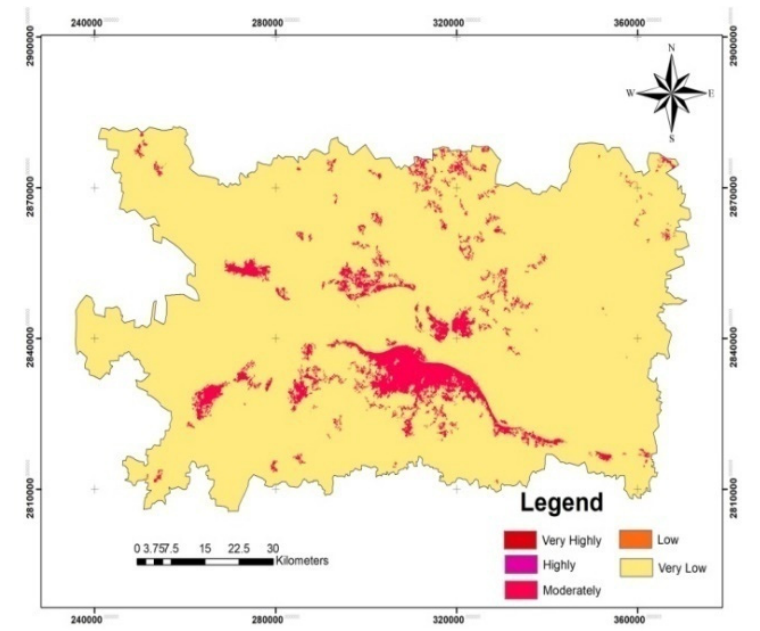

(t)

Figure 3. Cont. 


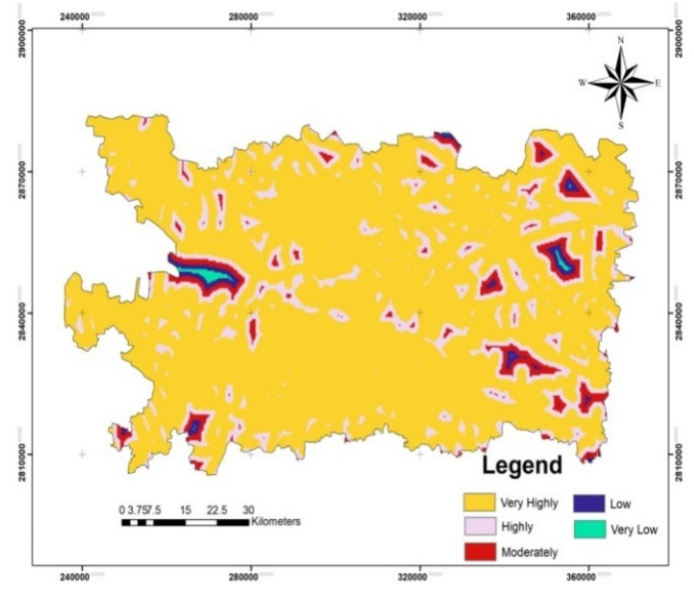

(u)

Figure 3. Flood susceptibility sub-criteria maps: (a) Precipitation, (b) river network density, (c) SPI, (d) elevation, (e) slope, (f) profile curvature, (g) landforms, (h) ruggedness index, (i) distance form river, (j) soil type, (k) soil moisture, (l) TWI, (m) soil erodibility factor, (n) rainfall erosivity factor, (o) LU/LC, (p) SAVI, (q) NDVI, (r) population density, (s) GMIS, (t) HBSE, and (u) distance to roads network.

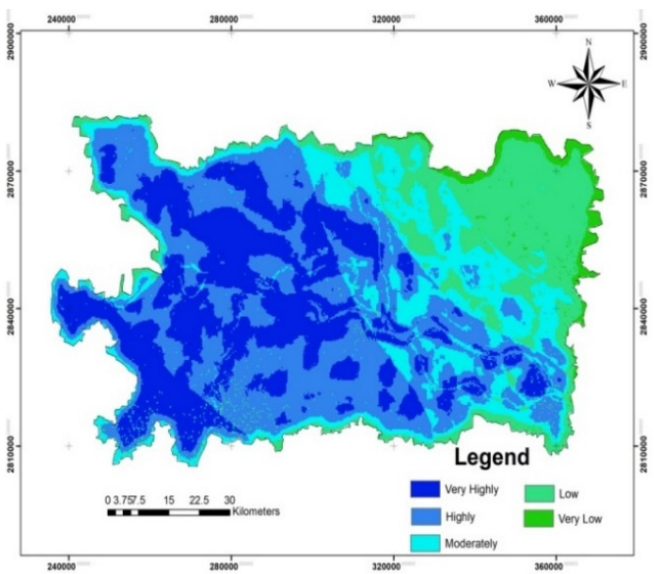

(a)

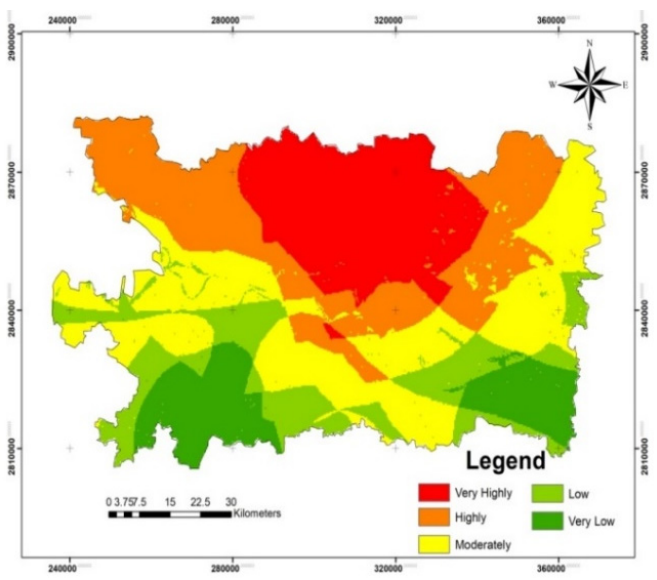

(c)

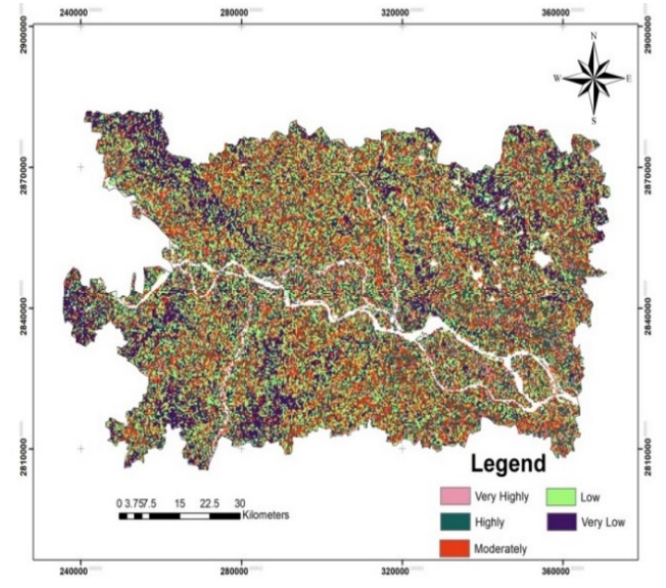

(b)

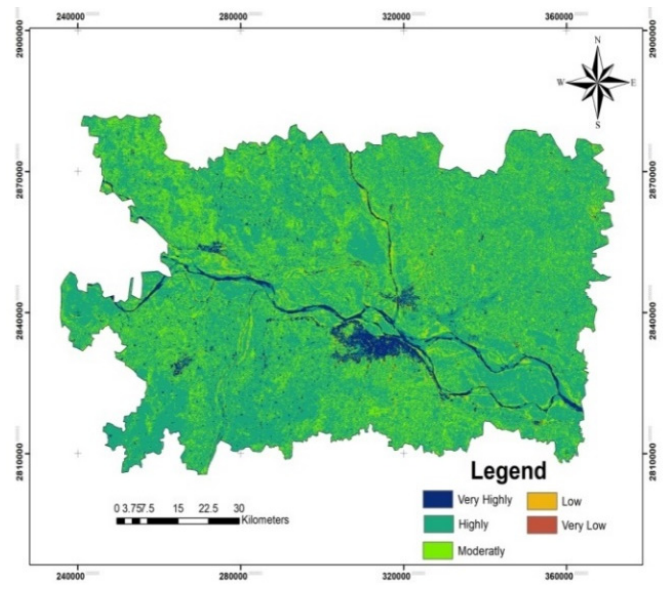

(d)

Figure 4. Cont. 


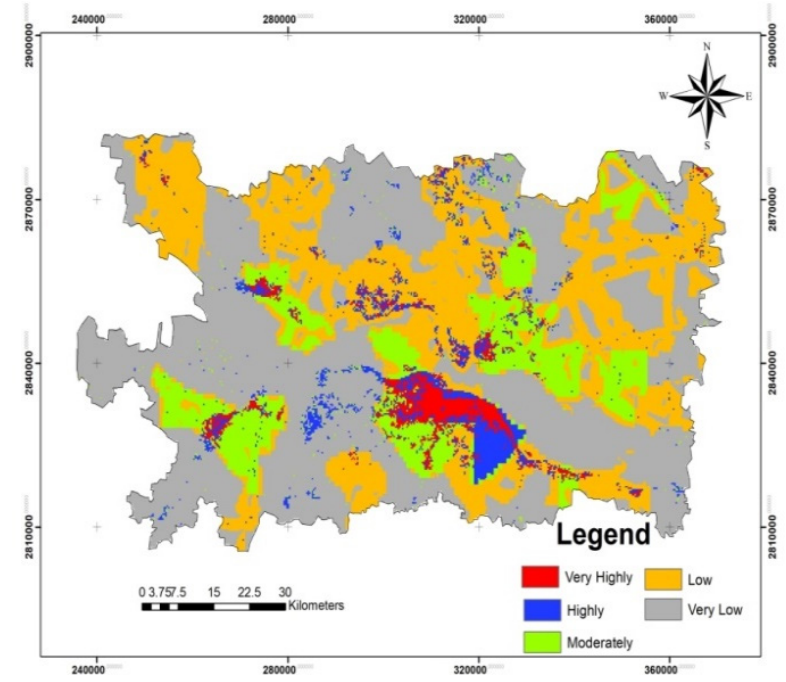

(e)

Figure 4. Primary flood susceptibility criteria map; (a) hydrologic, (b) morphometric, (c) permeability, (d) land cover dynamics, (e) anthropogenic.

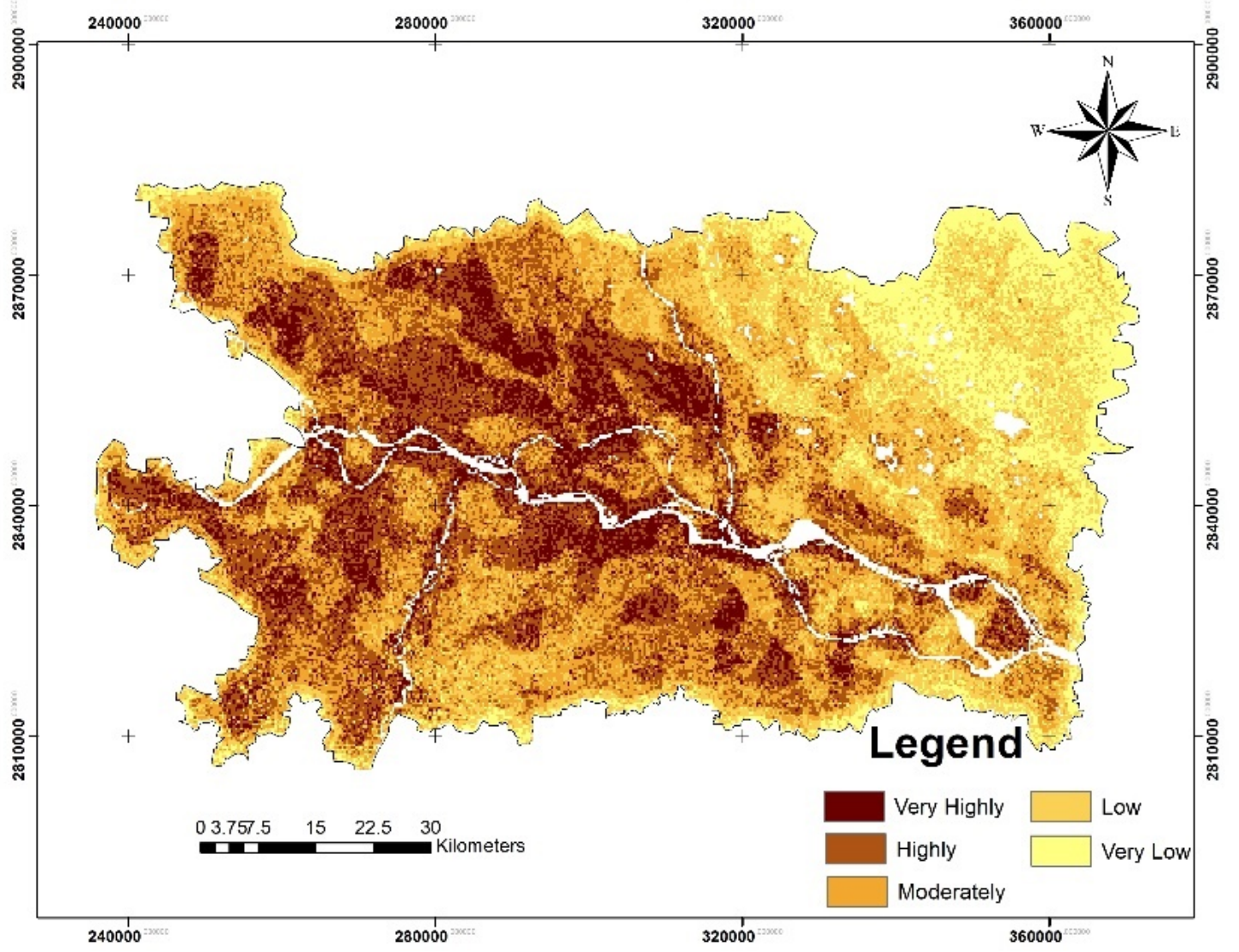

Figure 5. Final flood susceptibility map. 
Table 5. Area coverage of flood susceptibility classes.

\begin{tabular}{ccccccccccc}
\hline Criteria & $\begin{array}{c}\text { Very High, } \\
\text { sq km }\end{array}$ & $\%$ & $\begin{array}{c}\text { High, } \\
\text { sq km }\end{array}$ & $\%$ & $\begin{array}{c}\text { Moderate, } \\
\text { sq km }\end{array}$ & $\%$ & $\begin{array}{c}\text { Low, } \\
\text { sq km }\end{array}$ & $\begin{array}{c}\text { Very Low, } \\
\text { sq km }\end{array}$ & $\%$ \\
\hline Hydrologic & 2057.73 & 27.8 & 2531.3 & 34.3 & 1324.36 & 17.9 & 1355.2 & 18.3 & 119.44 & 1.62 \\
\hline Morphometric & 405.83 & 5.49 & 1389.1 & 18.8 & 1965.14 & 26.6 & 2118.7 & 28.7 & 1509.28 & 20.4 \\
\hline Permeability & 1513.60 & 20.5 & 1773.4 & 24.0 & 2084.08 & 28.2 & 1104.0 & 14.9 & 912.94 & 12.4 \\
\hline $\begin{array}{c}\text { Land cover } \\
\text { dynamics }\end{array}$ & 314.20 & 4.3 & 5117.9 & 69.2 & 1897.84 & 25.6 & 57.42 & 0.78 & 0.55 & 0.01 \\
\hline Anthropogenic & 159.290 & 2.2 & 294.22 & 3.98 & 906.82 & 12.2 & 2346.3 & 31.7 & 3681.27 & 49.8 \\
\hline $\begin{array}{c}\text { Final flood } \\
\text { susceptibility }\end{array}$ & 1002.710 & 13.6 & 1978.9 & 26.7 & 1956.17 & 26.5 & 1536.6 & 20.8 & 913.49 & 12.4 \\
\hline
\end{tabular}

\subsection{Validation with Sentinel 1 C Images}

Sentinel $1 \mathrm{C}$ radarsat data were collected for before and after the flood event (Figure 6) in the study area during September 2019. The GEE code editor tool was used to estimate VV and VH backscatter values $(\mathrm{dB})$ for pre- and post-flood instances through thresholding. The flooded area map showed that major flooding had occurred along the basins of Ganga and Gandak rivers. However, water logging is observed in areas in various parts of the study area, which may be attributed to heavy monsoon rain events (Figure 6).

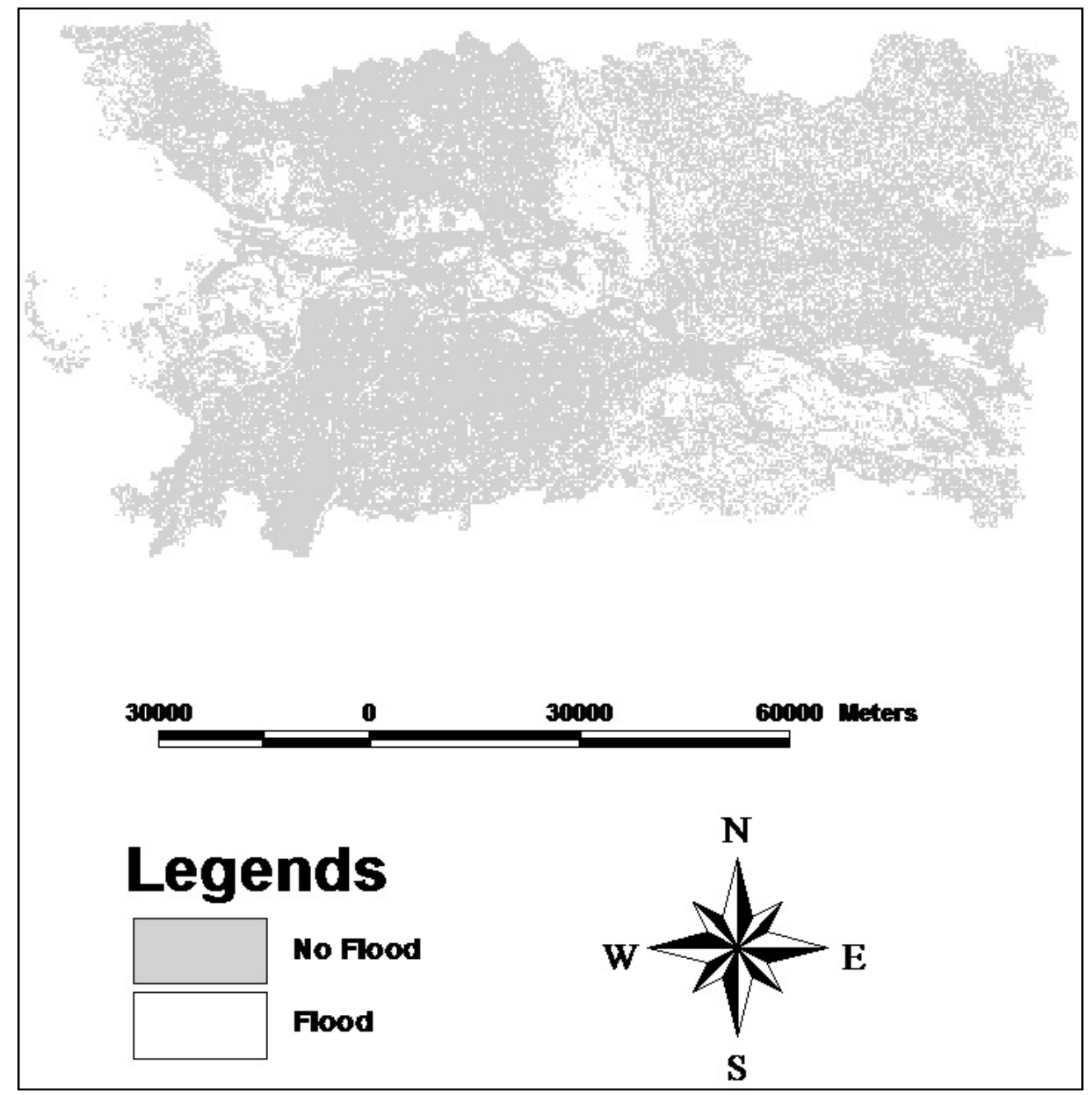

Figure 6. Flooding in 2019 in the study area. 
The 2019 flood map was compared with the final flood susceptibility map developed through the AHP-GIS/RS technique on cloud platform. The "Map Query" operation was carried out for the flooded area against the area classified as the very high and high flood susceptibility class map (Figure 7). According to the resultant map, major flooding was found in areas classified as showing very high and high susceptibility to flood. This result showed the validity of the susceptibility map, which can be an early warning system against flood events. However, the exact percentage of validity may differ as floods mostly occurred in areas with weak earthen embankment structures, with water flowing above the dangerous level during the rainy season.

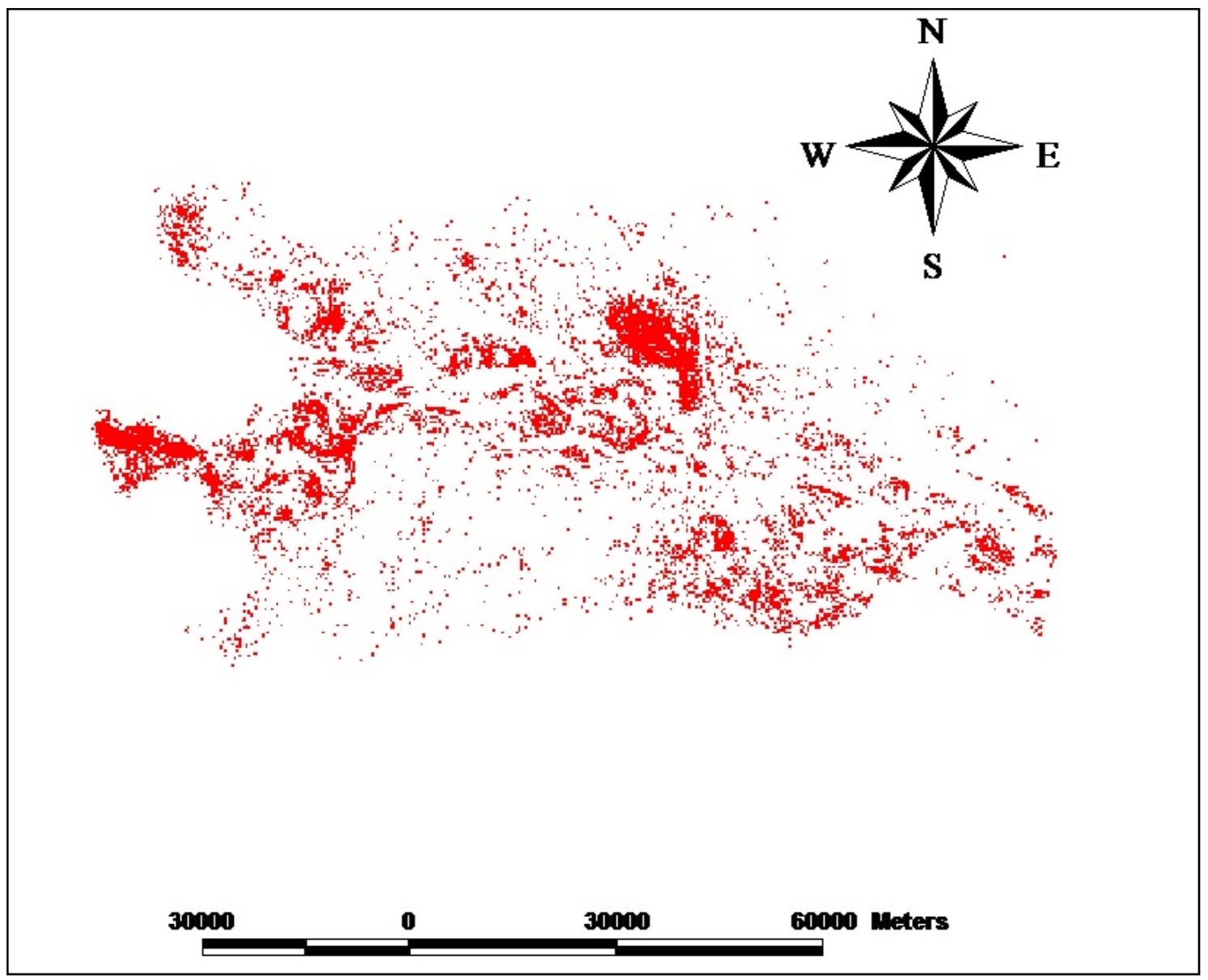

Figure 7. Flood occurrence map in flood susceptible zones (under very high and high classes).

\subsection{Flood Susceptible Zone near the River}

Further analysis of the location and distribution of the flood susceptible zone in the study area was carried out using the "Map Query" tool in Arc GIS to examine the direct impact of rivers' flow paths (Figure 8). The analysis showed that nearly $83 \%$ of flood susceptible zones (under very highly and highly susceptible zones) are located within $500 \mathrm{~m}$ of the river bank and the remaining $17 \%$ of flood susceptible zones are located further away from the river basin. The "Map Query" tool can be further used to analyze the impact of individual criterion on final susceptible zone mapping. This validates and enhances the applicability of the AHP-GIS technique for flood susceptible mapping in the study area. 


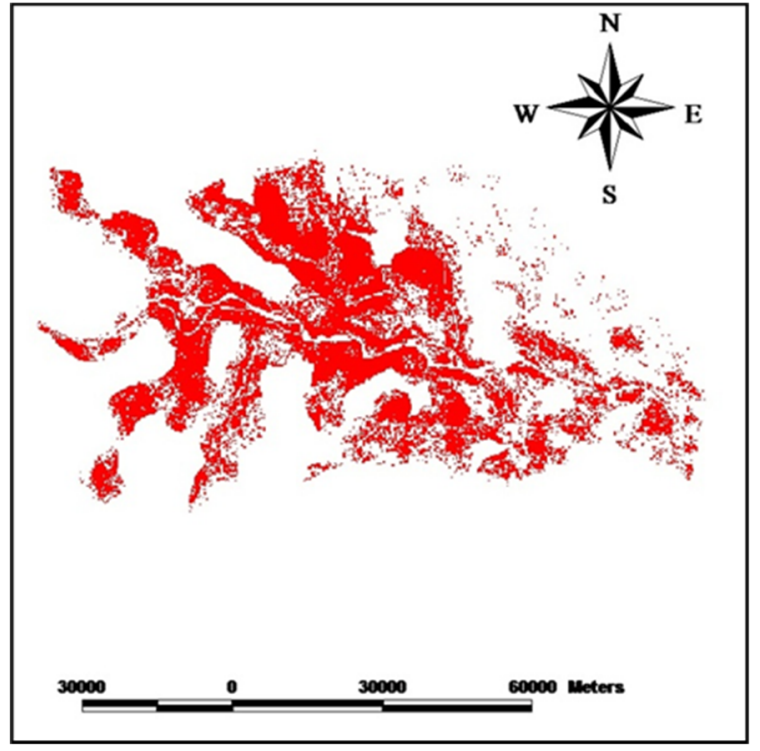

(a)

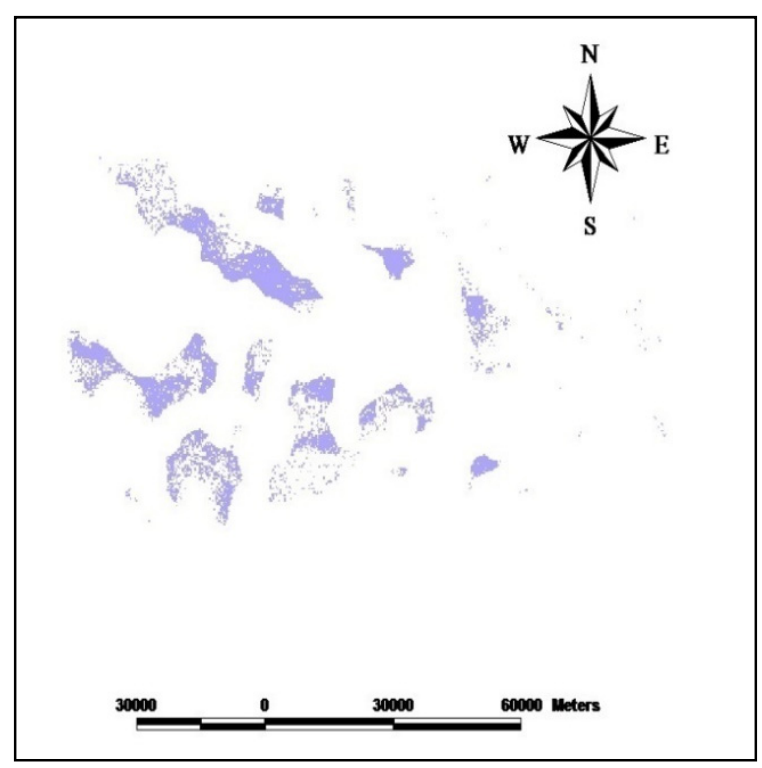

(b)

Figure 8. Flood susceptible zone with respect to distance from river; (a) susceptible zone $<500 \mathrm{~m}$, (b) susceptible zone $>500 \mathrm{~m}$.

\subsection{Discussion}

The study area is located in the Indo-Gangetic plain, hosting many rivers, such as Burhi-Gandak, Gandak, Ghaghra, Kosi Mahananda, and Ganga. As expected, areas in the vicinity of these rivers were found to be most susceptible to floods. The Kosi river (The Sorrow of Bihar), as its nature quickly and frequently changes its course, causing floods every alternate year. In this study, the methodology adopted showed that hydrologic criteria have a higher influence in determining flood susceptibility areas. In other studies, hydrologic-SPI was considered as the leading parameter causing frequent floods [57]. However, low-quality embankment structures, deforestation at river banks, sediment deposition, and non-removal of sediment from dams and barrages are some factors that may cause floods at river banks [58]. Heavy rains in Nepal can also cause flash floods in northern districts of Bihar. Districts in Bihar, such as Bhojpur, Khagaria, Buxar, Vaishali, Samastipur, Bhagalpur, and Patna, are more prone to floods due to very low slopes.

AHP is a simple and executable weighing technique, though it depends on experts' opinions and judgments during the initial stages for assigning weights to different criteria, which may introduce some uncertainty. AHP is suitable for local and regional susceptibility studies [23] and mostly influenced by local hydrological, hydrogeological, and morphological characteristics. Researchers have determined that rainfall, topography, and soil significantly influence the occurrence of floods [59], which is inline with our results. Flood susceptibility mapping can be improved using modern techniques, such as the naïve Bayes method of alternating decision tree (AD Tree) and random forest (RF) $[60,61]$ and frequency ratio and support vector machine models $[62,63]$.

The flood susceptibility map was further validated with a radarsat images-based flood map for 2019. The qualitative validation showed that the majority of the flooding occurred in areas that can be classified as very highly and highly flood susceptible.

\section{Conclusions}

Flood disaster susceptible zone mapping is one of the most constructive methods that allows a reduction offlood hazard damages and assist planners, stakeholders, and decision-makers to have proper supervision over the flood-prone areas, ensuring proper and sustainable socio-economic development. The remote sensing GEE-based multi-parametric AHP-GIS technique is a sound 
alternative approach to identify the flood susceptibility zones in the state of Bihar, India. For total flood susceptibility evaluation, 21 criteria were grouped into 5 primary criteria based on their proximity and relative level of influence in causing flood. Each and every flood affecting the raster layer was processed in the code editor GEE API platform and then reclassified in the GIS environment for flood susceptibility map development. Using Saaty's AHP technique, the hydrologic criterion was given the highest rank for finding areas susceptible to flooding, followed by morphometric criterion, permeability, land cover dynamics, and anthropogenic interference. An area of $\sim 3000 \mathrm{sq} \mathrm{km}(40.36 \%)$ was concentrated in high to very high flood susceptibility zones that were in the vicinity of rivers, whereas an area of $\sim 1000 \mathrm{sq} \mathrm{km}(12 \%)$ had very low flood susceptibility. The GIS-AHP technique provided useful insights for flood zone mapping when a higher number of parameters were used in GEE. The majority of the detected flood-susceptible areas flooded during the 2019 floods and was mostly located within $500 \mathrm{~m}$ of the rivers' paths.

Author Contributions: Investigation, Kishore Chandra Swain; Methodology, Kishore Chandra Swain, Chiranjit Singha and Laxmikanta Nayak; Project administration, Laxmikanta Nayak; Resources, Chiranjit Singha; Software, Kishore Chandra Swain; Validation, Chiranjit Singha and Laxmikanta Nayak. All authors have read and agreed to the published version of the manuscript.

Funding: This research received no external funding.

Acknowledgments: We do acknowledge the Visva-Bharati University for hosting this research work.

Conflicts of Interest: The authors declare that there is no conflict of interest.

\section{References}

1. Giordan, D.; Notti, D.; Villa, A.; Zucca, F.; Calo, F.; Pepe, A. Low cost, multiscale and multi-sensor application for flooded area mapping. Nat. Hazards Earth Syst. Sci. 2018, 18, 1493-1516. [CrossRef]

2. Sofia, G.; Roder, G.; Dalla Fontana, G.; Tarolli, P. Flood dynamics in urbanised landscapes: 100 years of climate and humans' interaction. Sci. Rep. 2017, 7, 40527. [CrossRef] [PubMed]

3. Smith, A.; Bates, P.D.; Wing, O.; Sampson, C.; Quinn, N.; Neal, J. New estimates of flood exposure in developing countries using high-resolution population data. Nat. Commun. 2019, 10, 1814. [CrossRef] [PubMed]

4. Souissi, D.; Zouhri, L.; Hammami, S.; Msaddek, M.H.; Zghibi, A.; Dlala, M. GIS-based MCDM-AHP modeling for flood susceptibility mapping of arid areas, southeastern Tunisia. Geocarto Int. 2019, 35, 991-1017. [CrossRef]

5. Pradhan, B. Flood susceptible mapping and risk area delineation using logistic regression, GIS and Remote sensing. J. Spat. Hydrol. 2009, 9, 1-18.

6. Siahkamari, S.; Haghizadeh, A.; Zeinivand, H.; Tahmasebipour, N.; Rahmati, O. Spatial prediction of flood-susceptible areas using frequency ratio and maximum entropy models. Geocarto Int. 2018, 33, 927-941. [CrossRef]

7. Shafapour-Tehrany, M.; Shabani, F.; NeamahJebur, M.; Hong, H.; Pourghasemi, H.R.; Xie, X. GIS-based spatial prediction of flood prone areas using standalone frequency ratio, logistic regression, weight of evidence and their ensemble techniques. Geomat. Nat. Hazards Risk 2017, 8, 1538-1561. [CrossRef]

8. Liu, K.; Li, Z.; Yao, C.; Chen, J.; Zhang, K.; Saifullah, M. Coupling the k-nearest neighbor procedure with the Kalman filter for real-time updating of the hydraulic model in flood forecasting. Int. J. Sediment Res. 2016, 31, 149-158. [CrossRef]

9. Dano, U.; Balogun, A.L.; Matori, A.N.; Wan Yusouf, K.; Rimi Abubakar, I.; Said Mohamed, M.; Pradhan, B. Flood Susceptibility Mapping Using GIS-Based Analytic Network Process: A Case Study of Perlis, Malaysia. Water 2019, 11, 615. [CrossRef]

10. Li, Y.; Martinis, S.; Wieland, M.; Schlaffer, S.; Natsuaki, R. Urban Flood Mapping Using SAR Intensity and Interferometric Coherence via Bayesian Network Fusion. Remote Sens. 2019, 11, 2231. [CrossRef]

11. Darabi, H.; Choubin, B.; Rahmati, O.; Haghighi, A.T.; Pradhan, B.; Kløve, B. Urban flood risk mapping using the GARP and QUEST models: A comparative study of machine learning techniques. J. Hydrol. 2019, 569, 142-154. [CrossRef] 
12. Termeh, S.V.R.; Kornejady, A.; Pourghasemi, H.R.; Keesstra, S. Flood susceptibility mapping using novelensembles of adaptive neuro fuzzy inference system and metaheuristic algorithms. Sci. Total Environ. 2018, 615, 438-451. [CrossRef] [PubMed]

13. Rahmati, O.; Zeinivand, H.; Besharat, M. Flood hazard zoning in Yasooj region, Iran, using GIS and multi-criteria decision analysis. Geomat. Nat. Hazards Risk 2016, 7, 1000-1017. [CrossRef]

14. Oeurng, C.; Sauvage, S.; Sánchez-Pérez, J.M. Assessment of hydrology, sediment and particulate organic carbon yield in a large agricultural catchment using the SWAT model. J. Hydrol. 2011, 401, 145-153. [CrossRef]

15. Choubin, B.; Moradi, E.; Golshan, M.; Adamowski, J.; Sajedi-Hosseini, F.; Mosavi, A. An ensemble prediction of flood susceptibility using multivariate discriminant analysis, classification and regression trees, and support vector machines. Sci. Total Environ. 2019, 651, 2087-2096. [CrossRef]

16. Hong, H.; Tsangaratos, P.; Ilia, I.; Liu, J.; Zhu, A.X.; Chen, W. Application of fuzzy weight of evidence and data mining techniques in construction of flood susceptibility map of Poyang County, China. Sci. Total Environ. 2018, 625, 575-588. [CrossRef]

17. Khosravi, K.; Pham, B.T.; Chapi, K.; Shirzadi, A.; Shahabi, H.; Revhaug, I.; Prakash, I.; Bui, D.T. A comparative assessment of decision trees algorithms for flash flood susceptibility modeling at Haraz watershed, Northern Iran. Sci. Total Environ. 2018, 627, 744-755. [CrossRef]

18. Wang, Y.; Fang, Z.; Hong, H.; Peng, L. Flood susceptibility mapping using convolutional neural network frameworks. J. Hydrol. 2020, 582, 124482. [CrossRef]

19. Jahangir, M.H.; Reineh, S.M.M.; Abolghasemi, M. Spatial predication of flood zonation mapping in Kan River Basin, Iran, using artificial neural network algorithm. Weather Clim. Extrem. 2019, 25, 100215. [CrossRef]

20. Duan, Q.; Sorooshian, S.; Gupta, V. Effective and efficient global optimization for conceptual rainfall-runoff models. Water Resour. Res. 1992, 28, 1015-1031. [CrossRef]

21. Bahrami, S. Global Ensemble Stream Flow and Flood Modeling with Application of Large Data Analytics, Deep Learning and GIS. Unpublished Master's Thesis, University of Naved, Reno, NV, USA, 2019; p. 210.

22. Tellman, B.; Kuhn, C.; Max, S.A.; Sullivan, J. Dynamic Flood Vulnerability Mapping with Google Earth Engine. In Proceedings of the American Geophysical Union Fall Meeting, San Francisco, CA, USA, 14-18 December 2015; pp. 5523-5527.

23. Liu, C.C.; Shieh, M.C.; Ke, M.S.; Wang, K.H. Flood Prevention and Emergency Response System Powered by Google Earth Engine. Remote Sens. 2018, 10, 1283. [CrossRef]

24. Vojtek, M.; Vojteková, J. Flood Susceptibility Mapping on a National Scale in Slovakia Using the Analytical Hierarchy Process. Water 2019, 11, 364. [CrossRef]

25. Yahaya, S.; Ahmad, N.; Abdalla, R.F. Multicriteria analysis for flood vulnerable areas in Hadejia-Jama'are River basin, Nigeria. Eur. J. Sci. Res. 2010, 42, 71-83.

26. India Water Portal. Bihar Floods 2008 Archived 1 February 2009 at the Wayback Machine. 2009. Available online: https://www.indiawaterportal.org/ (accessed on 2 February 2020).

27. GhorbaniNejad, S.; Falah, F.; Daneshfar, M.; Haghizadeh, A.; Rahmati, O. Delineation of groundwater potential zones using remote sensing and GIS-based data-driven models. Geocarto Int. 2017, 32, 167-187.

28. Shahabi, H.; Shirzadi, A.; Ghaderi, K.; Omidvar, E.; Al-Ansari, N.; Clague, J.J.; Geertsema, M.; Khosravi, K.; Amini, A.; Bahrami, S.; et al. Flood Detection and Susceptibility Mapping Using Sentinel-1 Remote Sensing Data and a Machine Learning Approach: Hybrid Intelligence of Bagging Ensemble Based on K-Nearest Neighbor Classifier. Remote Sens. 2020, 12, 266. [CrossRef]

29. Fernández, D.S.; Lutz, M.A. Urban flood hazard zoning in Tucumán Province, Argentina, using GIS and multicriteria decision analysis. Eng. Geol. 2010, 111, 90-98. [CrossRef]

30. Beven, K.J.; Kirkby, M.J.A. Physically based, variable contributing area model of basin hydrology/Un modèle à base physique de zone d'appel variable de l'hydrologie du basin versant. Hydrol. Sci. J. 1979, 24, 43-69. [CrossRef]

31. Bilskie, M.V.; Hagen, S.C.; Medeiros, S.C.; Passeri, D.L. Dynamics of sea level rise and coastal flooding on a changing landscape. Geophy. Res. Lett. 2014, 41, 927-934. [CrossRef]

32. Kourgialas, N.N.; Karatzas, G.P. Flood management and a GIS modelling method to assess flood-hazard areas-A case study. Hydrol Sci. J. 2011, 56, 212-225. [CrossRef]

33. Tehrany, M.S.; Pradhan, B.; Jebur, M.N. Flood susceptibility mapping using a novel ensemble weights-of-evidence and support vector machine models in GIS. J. Hydrol. 2014, 512, 332-343. [CrossRef] 
34. Malinowski, R.; Groom, G.; Schwanghart, W.; Heckrath, G. Detection and Delineation of Localized Flooding from WorldView-2 Multispectral Data. Remote Sens. 2015, 7, 14853-14875. [CrossRef]

35. CIESIN. Center for International Earth Science Information Network, Gridded Population of the World (GPWv3); CIESIN, Columbia University, and Centro Internacional de Agricultura Tropical: Palisades, NY, USA, 2005.

36. Jebur, M.N.; Pradhan, B.; Tehrany, M.S. Optimization of landslide conditioning factors using very high-resolution airborne laser scanning (LiDAR) data at catchment scale. Remote Sens. Environ. 2014, 152, 150-165. [CrossRef]

37. Diwakar, S.K.; Nagarkoti, J. Performance of WRF (ARW) over River Basins under Flood Met Office, Patna during Flood Season-2014; Indian Meteorological Department: New Delhi, India, 2016; p. 30. [CrossRef]

38. FMIS. Flood Management Information System (FMIS), Water Resource Department, Bihar. 2019. Available online: http://fmis.bih.nic.in/mapWRD_INUN.html (accessed on 8 May 2019).

39. Dube, M. Bihar Floods: A Report on Bihar Floods 2016; Bihar Disaster Management Authority, Government of Bihar: Patna, India, 2018; p. 36.

40. Drobot, R. Methodology for Determining Torrential Catchments in Which Human Settlements Are Exposed to Flash Floods; Technical University of Civil Engineering: Bucharest, Romania, 2007. (In Romanian)

41. Amin, K. Application of Remote Sensing and GIS in Flash Flood Hazard Mapping and Hydraulic Design (Case Study of Wadi Dahdah, Saudi Arabia). 2019. Available online: https://www.academia.edu/20126182/ Application_of_Remote_Sensing_and_GIS_for_Floodplain_mapping_and_Hydraulic_design (accessed on 1 January 2020).

42. Al-Saady, Y.I.; Al-Suhail, Q.A.; Al-Tawash, B.S.; Othman, A.A. Drainage network extraction and morphometric analysis using remote sensing and GIS mapping techniques (Lesser Zab River Basin, Iraq and Iran). Environ. Earth Sci. 2016, 75, 1243. [CrossRef]

43. Musy, A.; Higy, C. Hydrology. A Science of Nature; CRC Press, Taylor \& Francis Group, Science Publishers: Enfield, NH, USA, 2011.

44. Ochoa, P.; Fries, A.; Mejía, D.; Burneo, J.; Ruíz-Sinoga, J.; Cerdà, A. Effects of climate, land cover and topography on soil erosion risk in a semiarid basin of the Andes. Catena 2016, 140, 31-42. [CrossRef]

45. Renard, K.G.; Foster, G.R.; Weesies, G.A. Predicting soil erosion by water: A guide to conservation planning with the revised universal soil loss equation (RUSLE). In Agriculture Handbook Number 703; USDA-ARS: Washington, DC, USA, 1997; p. 404

46. Goffi, A.; Stroppiana, D.; Brivio, P.A.; Bordogna, G.; Boschetti, M. Towards an automated approach to map flooded areas from Sentinel-2 MSI data and soft integration of water spectral features. Int. J. Appl. Earth Obs. Geoinf. 2020, 84, 101951. [CrossRef]

47. Tucker, C.J. Red and photographic infrared linear combinations for monitoring vegetation. Remote Sens. Environ. 1979, 8, 127-150. [CrossRef]

48. Huete, A.R. A soil-adjusted vegetation index (SAVI). Remote Sens. Environ. 1988, 25, 295-309. [CrossRef]

49. Center for International Earth Science Information Network-CIESIN_Columbia University (CIESIN). Gridded Population of the World, Version 4 (GPWv4): Basic Demographic Characteristics, Revision 11; NASA Socioeconomic Data and Applications Center (SEDAC): Palisades, NY, USA, 2018. Available online: https: //sedac.ciesin.columbia.edu/data/collection/gpw-v4 (accessed on 10 May 2019). [CrossRef]

50. Pesaresi, M.; Ehrilch, D.; Florczyk, A.J.; Freire, S.; Julea, A. GHS Built-Upgrid, Derived from Landsat, Multitemporal (1975, 1990, 2000, 2014) (versionR2015); European Commission, Joint Research Centre (JRC): Ispra, Italy, 2019. Available online: http://data.europa.eu/89h/jrc-ghsl-hs_built_ldsmt_globe_r2015b (accessed on 21 April 2019).

51. Ayalew, L.; Yamagishi, H. The application of GIS-based logistic regression for landslide susceptibility mapping in the Kakuda-Yahiko Mountains, Central Japan. Geomorpho 2005, 65, 15-31. [CrossRef]

52. Singha, C.; Swain, K.C. Land Suitability Evaluation Criteria for Agricultural crop selection: A Review. Agric. Rev. 2016, 37, 125-132. [CrossRef]

53. Saaty, T.L. The Analytical Hierarchy Process; McGraw Hill: New York, NY, USA, 1980.

54. Luu, C.; Von Meding, J.; Kanjanabootra, S. Assessing flood hazard using flood marks and analytic hierarchy process approach: A case study for the 2013 flood event in Quang Nam, Vietnam. Nat. Hazards 2018, 90, 1031-1050. [CrossRef]

55. Saaty, T.L.; Vargas, G.L. Models, Methods, Concepts, and Applications of the Analytic Hierarchy Process. Int. Ser. Oper. Res. Manag. Sci. 2001, 32, 93. [CrossRef] 
56. Drobne, S.; Lisec, A. Multi-attribute decision analysis in GIS: Weighted linear combination and ordered weighted averaging. Informatica 2009, 33, 459-474.

57. Singha, C.; Swain, K.C.; Saren, B.K. Land Suitability Assessment for Potato Crop using Analytic Hierarchy Process Technique and Geographic Information System. J. Agric. Eng. 2019, 56, 78-87. Available online: http://www.isae.in/journal_jae.aspx (accessed on 10 August 2020).

58. Al-Abadi, A.M.; Shahid, S.; Al-Ali, A.K.A. GIS-based integration of catastrophe theory and analytical hierarchy process for mapping flood susceptibility: A case study of Teeb area, Southern Iraq. Environ. Earth Sci. 2016, 75, 687. [CrossRef]

59. Santangelo, N.; Santo, A.; Di Crescenzo, G.; Foscari, G.; Liuzza, V.; Sciarrotta, S.; Scorpio, V. Flood susceptibility assessment in a highly urbanized alluvial fan: The case study of Sala Consilina (southern Italy). Nat. Hazards Earth Syst. Sci. 2011, 11, 2765-2780. [CrossRef]

60. Seejata, K.; Yodying, A.; Wongthadam, T.; Mahavik, N.; Tantanee, S. Assessment of flood hazard areas using Analytical Hierarchy Process over the Lower Yom Basin, Sukhothai Province. Procedia Eng. 2018, 212, 340-347. [CrossRef]

61. Tanga, X.; Lib, J.; Liuc, M.; Liud, W.; Hong, H. Flood susceptibility assessment based on a novel random Naïve Bayes method: A comparison between different factor discretization. Catena 2019, 189, 104536. [CrossRef]

62. Chen, W.; Li, Y.; Xue, W.; Shahabi, H.; Li, S.; Hong, H.; Bin Ahmad, B. Modeling flood susceptibility using data-driven approaches of naïve Bayes tree, alternating decision tree, and random forest methods. Sci. Total Environ. 2019, 701, 134979. [CrossRef]

63. Sahana, M.; Rehman, S.; Sajjad, H.; Hong, H. Exploring effectiveness of frequency ratio and support vector machine models in storm surge flood susceptibility assessment: A study of Sundarban Biosphere Reserve, India. Catena 2020, 189, 104450. [CrossRef]

Publisher's Note: MDPI stays neutral with regard to jurisdictional claims in published maps and institutional affiliations. 